National Assessment Of Shoreline Change: Part 2 Historical Shoreline Changes And Associated Coastal Land Loss Along The U.S. Southeast Atlantic Coast

By Robert A. Morton and Tara L. Miller

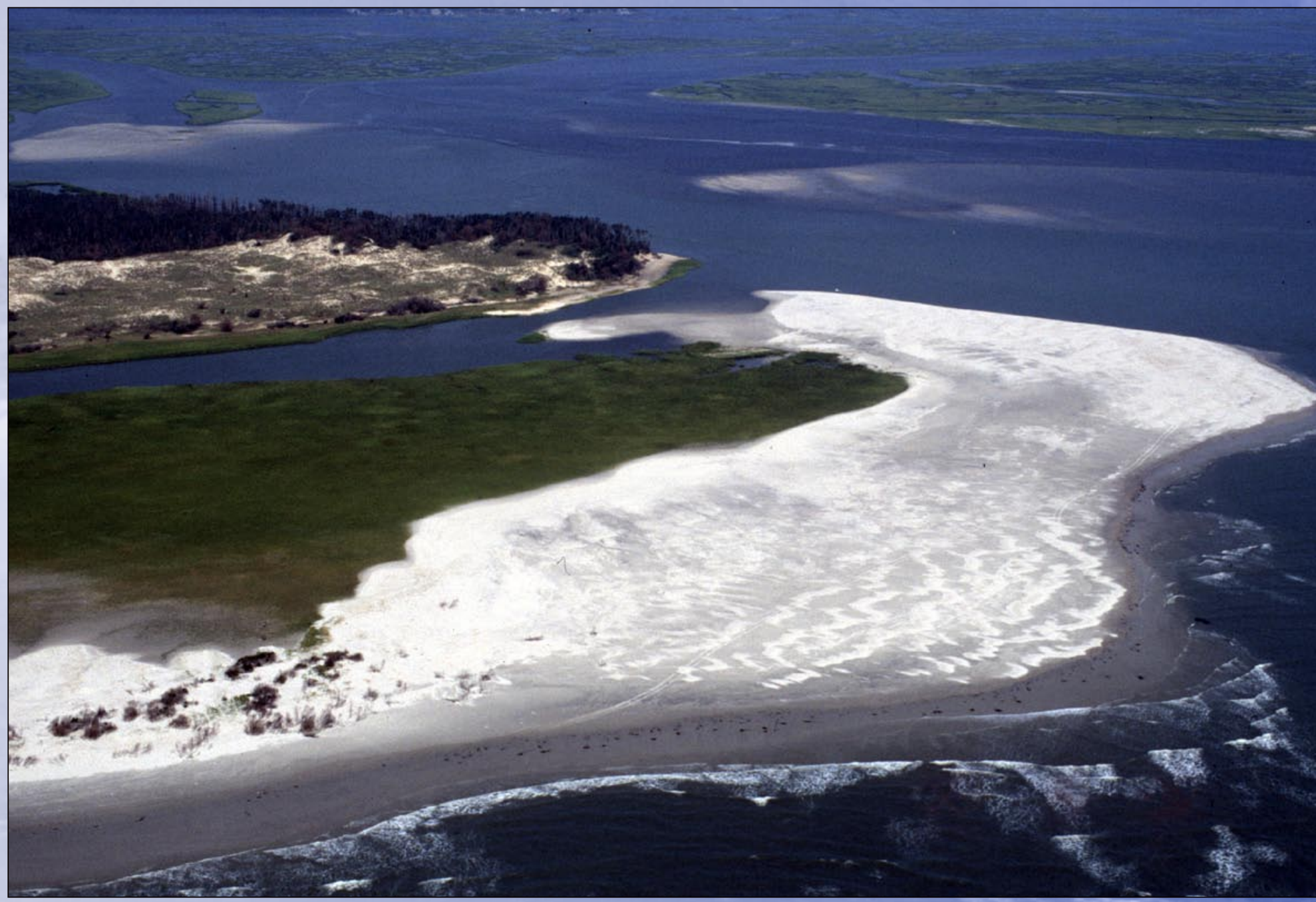

Open-File Report 2005-1401

U.S. Department of the Interior U.S. Geological Survey 


\section{National Assessment Of Shoreline Change: Part 2 Historical Shoreline Changes And Associated Coastal Land Loss Along The U.S. Southeast Atlantic Coast}

By Robert A. Morton ${ }^{1}$ and Tara L. Miller ${ }^{2}$

Open-File Report 2005-1401

1 U.S. Geological Survey

Center for Coastal and Watershed Studies

600 4th St. S.

St. Petersburg, FL 33701

2 IMSG, Inc.

NOAA Coastal Services Center

2234 South Hobson Avenue

Charleston, SC 29405

This report is preliminary and has not been reviewed for conformity with U.S. Geological Survey editorial standards. Any use of trade names is for descriptive purposes only and does not imply endorsement by the U.S. Government.

Morton, R. A., and Miller, T. L., 2005, National assessment of shoreline change: Part 2: Historical shoreline changes and associated coastal land loss along the U.S. Southeast Atlantic Coast: U.S. Geological Survey Open-file Report $2005-1401$.

\section{U.S. Department of the Interior \\ U.S. Geological Survey}




\section{Contents}

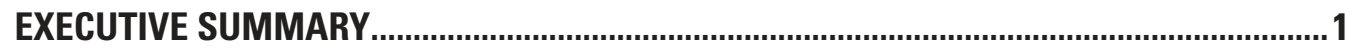

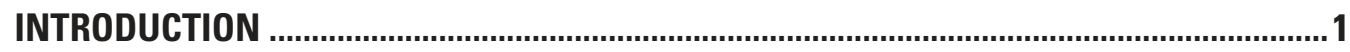

U.S. Geological Survey National Assessment of Shoreline Change............................. 1

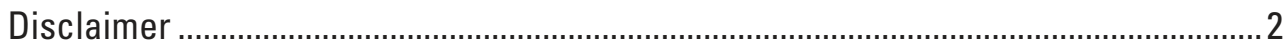

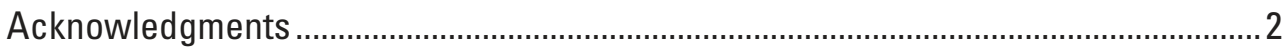

THE ROLE OF STATE AND FEDERAL GOVERNMENTS .................................................

PRIOR NATIONAL AND SOUTHEAST ATLANTIC SHORELINE ASSESSMENTS..................

METHODS OF ANALYZING SHORELINE CHANGE

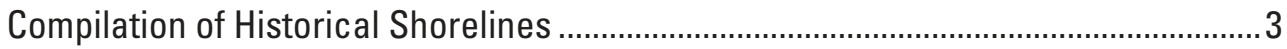

Delineation of a Modern (lidar-derived) Shoreline .................................................... 4

Geographic Information System (GIS) Procedures ................................................. 5

Calculation and Presentation of Rates of Change ................................................... 7

Shoreline Definitions and Beach Alterations that Influence Rates of Change ............ 8

Reliability of the Results ................................................................................

GEOMORPHOLOGY OF THE SOUTHEAST ATLANTIC REGION ......................................13

Southeast Atlantic Mainland Shores ………….................................................... 13

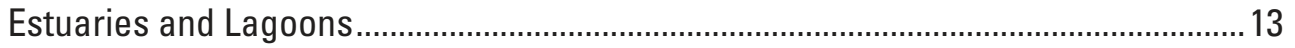

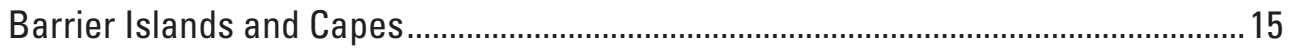

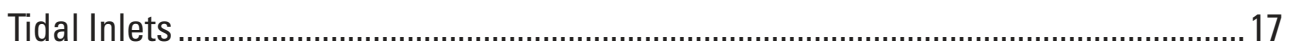

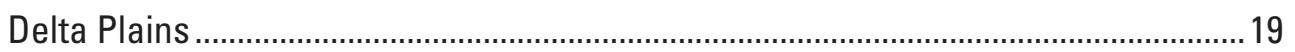

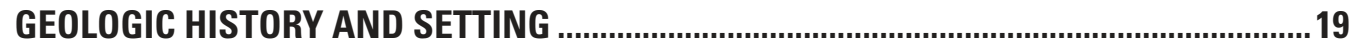

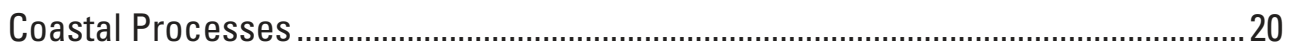

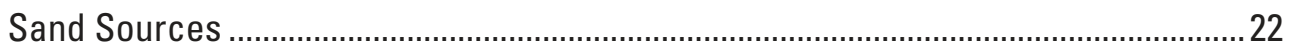

GENERAL CHARACTERISTICS OF THE SOUTHEAST ATLANTIC SHORES BY STATE.......23

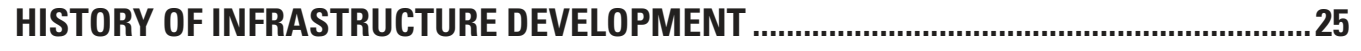

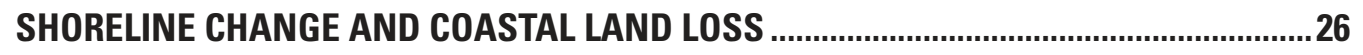

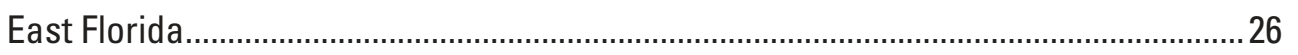

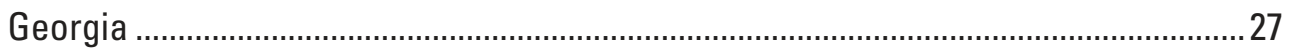

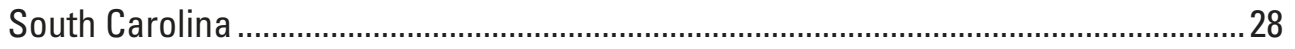

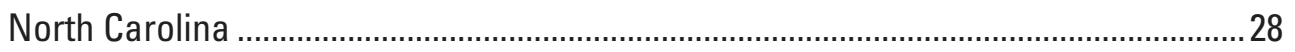

HUMAN RESPONSES TO COASTAL EROSION AND LAND LOSS..................................28

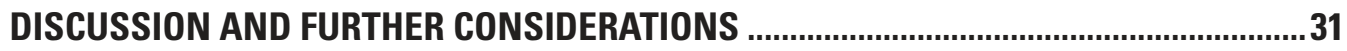

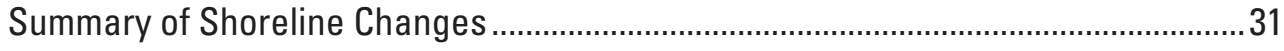

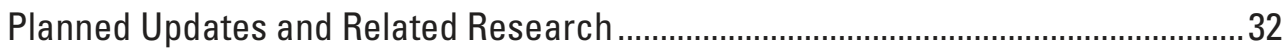

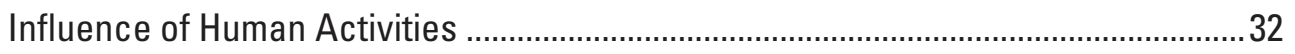

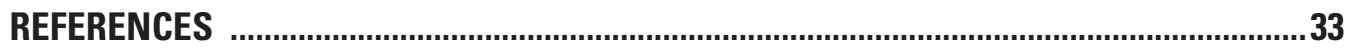




\section{Figures}

Figure 1A. Index map of the Southeast Atlantic region showing locations in Florida and Georgia.

Figure 1B. Index map of the Southeast Atlantic region showing locations in South Carolina and North Carolina.

Figure 2. Example of a lidar profile from September 26, 1997 at Kitty Hawk, North Carolina, for (A) the entire cross-shore region and $(B)$ an expanded view of the foreshore region......

Figure 3. Examples of common conditions where transects are eliminated in the absence of four shoreline intersections.

Figure 4. Common coastal landforms of the Southeast Atlantic region

Figure 5. Conceptual diagram showing possible origins of barrier islands 15

Figure 6. Sea-level curve during the past 140,000 years 16

Figure 7. Geomorphological characteristics of high- and low-profile barrier islands.

Figure 8. Former active sand dunes on Shackleford Banks, North Carolina. 18

Figure 9. Low, narrow barrier islands, such as those around Cape Romain, South Carolina, are overwashed frequently during storms.

Figure 10. Long linear beach ridges and swales 20

Figure 11. Tracks of some of the most deadly Atlantic and Gulf hurricanes in the 20th century...... 21

Figure 12. Erosion of the Atlantic shore can destroy roads and eliminate the beach. 22

Figure 13. Erosion and property damage near Floralton Beach, Florida caused by Hurricanes Francis and Jeanne in 2004.

Figure 14. Long-term trends in average annual sea level in the Southeast Atlantic 0cean 24

Figure 15. Jetty construction at Charleston Harbor, South Carolina caused chronic beach erosion on adjacent Morris Island

Figure 16. Outcrops of muddy marsh sediments on the lower beach are evidence of long-term erosion. ....26

Figure 17. Dead and fallen trees in the surf zone are indicators of long-term beach erosion.........................27

Figure 18. Multiple structures including a seawall and riprap revetment on Anatasia Island, Florida ..........30

Figure 19. Many beaches have been nourished to mitigate against long-term erosion ...................................30

Figure 20. Lateral relocation of a beach house in North Carolina........................................................................ 31 


\section{Tables}

Table 1. Prior reports of quantitative regional analyses of long-term historical shoreline movement that used shorelines derived from T-sheets and/or aerial photographs.

Table 2. Providers and original sources of historical shoreline data for each

Southeast Atlantic Coast state.

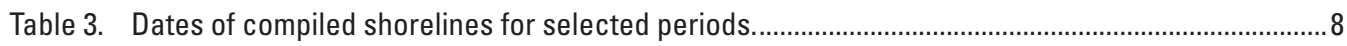

Table 4. List of tide-gauge measurements used to calculate mean high-water elevation............................. 10

Table 5. Absolute horizontal and vertical differences between high water and mean high water shorelines.. 12

Table 6. Maximum estimated measurement errors for Southeast Atlantic shorelines................................. 12

Table 7a. Long-term shoreline change trends, 1800s to post-1997 …........................................................... 13

Table 7b. Short-term shoreline change trends, 1960s to post-1997........................................................ 13

Table 8. Technical responses to erosion and land loss in the Southeast Atlantic region............................29 


\section{EXECUTIVE SUMMARY}

Beach erosion is a chronic problem along most openocean shores of the United States. As coastal populations continue to grow and community infrastructures are threatened by erosion, there is increased demand for accurate information regarding past and present trends and rates of shoreline movement. There is also a need for a comprehensive analysis of shoreline movement that is consistent from one coastal region to another. To meet these national needs, the U.S. Geological Survey is conducting an analysis of historical shoreline changes along open-ocean sandy shores of the conterminous United States and parts of Hawaii and Alaska. One purpose of this work is to develop standard repeatable methods for mapping and analyzing shoreline movement so that periodic updates regarding coastal erosion and land loss can be made nationally that are systematic and internally consistent.

This report on states comprising the Southeast Atlantic Coast (east Florida, Georgia, South Carolina, North Carolina) represents the second in a series that already includes the Gulf of Mexico and will eventually include the Northeast Atlantic Coast, Pacific Coast, and parts of Hawaii and Alaska. The report summarizes the methods of analysis, interprets the results, provides explanations regarding the historical and present trends and rates of change, and describes how different coastal communities are responding to coastal erosion. Shoreline change evaluations are based on comparing three historical shorelines with a recent shoreline derived from lidar (Light Detection and Ranging) topographic surveys. The historical shorelines generally represent the following periods: 1800 s, 1920s-1930s, and 1970s, whereas the lidar shoreline is 19982002. Long-term rates of change are calculated using four shorelines (1800s to lidar shoreline), whereas short-term rates of change are calculated for the most recent period (1970s to lidar shoreline). The historical rates of change presented in this report represent past conditions and therefore are not intended for predicting future shoreline positions or rates of change.

Rates of erosion for the Southeast Atlantic region were generally highest in South Carolina along barrier islands and headland shores associated with the Santee delta. Erosion was also rapid along some barrier islands in North Carolina. Highest rates of erosion in Florida were generally localized around tidal inlets. The most stable Southeast Atlantic beaches were along the east coast of Florida where low wave energy and frequent beach nourishment minimized erosion. Some beach segments in Florida accreted as a result of net longshore drift convergence around Cape Canaveral and around tidal inlets that were stabilized by jetties.

Seawalls, riprap revetments, and groins were constructed in all the Southeast Atlantic states as initial community responses to long-term beach erosion. Although some states, such as Florida, still permit shoreline stabilization structures, beach nourishment has become the preferred method of miti- gating long-term erosion. Beach nourishment is common in all of the Southeast Atlantic states except Georgia.

\section{INTRODUCTION}

\section{U.S. Geological Survey National Assessment of Shoreline Change}

Sandy ocean beaches of the United States represent some of the most popular tourist and recreational destinations, and they also constitute some of the most valuable real estate in the country. These ephemeral interfaces between water and land are the sites of intense residential and commercial development even though they are frequently subjected to natural hazards including flooding, storm impacts, coastal erosion, and tsunami inundation. Because population centers continue to shift toward the coast where valuable coastal property is vulnerable to erosion, the U.S. Geological Survey (USGS) is conducting a National Assessment of Coastal Change. One aspect of this effort, the National Assessment of Shoreline Change, uses shoreline position as a proxy for coastal change because shoreline position is one of the most commonly monitored indicators of environmental change (Morton, 1996), and it is easily understood by those who are interested in historical movement of beaches.

A principal purpose of the USGS shoreline change research is to develop a repeatable surveying methodology so that shorelines for the continental U.S., and portions of Hawaii and Alaska can be periodically and systematically updated in an internally consistent manner. In addition, new methods for determining datum-based shoreline positions and assessing coastal change will provide the opportunity to achieve more comprehensive assessments of error in the future. USGS primary objectives of this project are: (1) to develop and implement improved methods of assessing and monitoring shoreline movement, (2) to obtain a better understanding of the processes controlling shoreline movement, and (3) to enter into strategic partnerships to facilitate data dissemination.

Achieving these ongoing long-term objectives requires research that (1) examines the original sources of shoreline data [maps, air photos, global positioning system (GPS), lidar], (2) evaluates the utility of different shoreline proxies (geomorphic feature, water mark, tidal datum, elevation), including the errors associated with each method, (3) investigates the bias and potential errors associated with integrating different shoreline proxies from different sources, (4) develops standard uniform methods of shoreline-change analysis, (5) determines the effects of human activities on shoreline movement and rates of change, and (6) investigates mathematical methods for calculating historical rates of change and forecasting future rates of change. 
This report summarizes historical changes in the U.S. Southeast Atlantic shoreline, both accretion and erosion, but emphasizes the erosion hazard because it impacts natural resources and the economy. Shoreline erosion is also presented in the context of coastal land loss (http://pubs.usgs.gov/ of/2003/of03-337/), which is a much broader issue than beach erosion because it also includes bluff retreat and erosion and submergence of wetlands around interior bays and estuaries. The brief accounts of coastal land loss for each state provide a more comprehensive view of coastal processes and key references that can be used to learn more about coastal change in a broader context.

\section{Disclaimer}

Results of the National Assessment of Shoreline Change are organized by coastal regions. This report for the Southeast Atlantic region is the second in a series of reports that include text summarizing methods, results, and implications of the results in addition to maps, via Internet Map Server (IMS), illustrating rates of shoreline change. Rates of shoreline change are being published for the purpose of regional characterization. The shoreline-change results and products prepared by the USGS are not intended for comprehensive, detailed, site-specific analysis of shoreline movement, nor are they intended to replace any official sources of shoreline change information identified by local or state government agencies or other federal entities that are used for regulatory purposes. Rates of shoreline change presented herein may differ from other published rates, but differences do not necessarily indicate that either set of rates is inaccurate. Some discrepancies are expected, considering the many possible historic shorelines and ways of determining rates of change, and the inherent uncertainty in calculating these rates. Rates of shoreline change presented in this report represent shoreline movement under past conditions. The results are not intended for predicting future shoreline positions or rates of shoreline change. For official rates of shoreline change within each state, contact the following agencies: Florida Department of Environmental Protection Bureau of Beaches and Coastal Systems, Georgia Department of Natural Resources Coastal Resources Division, South Carolina Department of Health and Environmental Control, Office of Ocean and Coastal Resource Management, and North Carolina Department of Environment and Natural Resources Division of Coastal Management.

This publication was prepared by an agency of the United States Government. Neither the United States Government nor any agency thereof, nor any of their employees, makes any warranty, expressed or implied, or assumes any legal responsibility for the accuracy, completeness, or usefulness of any information apparatus, product, or process disclosed in the report, or represents that its use would not infringe privately owned rights. Reference to any specific commercial product, process, or service by trade name, trademark, manufacturer, or otherwise does not necessarily constitute or imply its endorsement, recommendation, or favoring by the United States Government or any agency thereof. Any views and opinions of authors expressed herein do not necessarily state or reflect those of the United States Government or any agency thereof.

\section{Acknowledgments}

This report was made possible by the hard work and generous cooperation of many individuals. We owe a debt of gratitude to Emmett Foster (Florida), Clark Alexander (Georgia), Susan Langley (Georgia), Dave Bush (Georgia), and Scott Harris (South Carolina) for providing electronic historical shorelines and accompanying metadata for their respective states. Compilation of historical shorelines in Georgia and South Carolina was funded by the USGS. We also thank Mike Rink (NOAA), Paul Frascione (Information Manufacturing Corporation), and Ben Oakley (Information Manufacturing Corporation) for providing scanned images of T-sheets or geo-referenced T-sheets, David Doyle (NOAA) for providing datum corrections so that T-sheets could be geo-referenced and digitized by the USGS, and Matt Stutz (Duke University) for providing information about beach nourishment projects. An enthusiastic and untiring USGS team was responsible for developing the methods and computer codes for calculating operational mean high-water elevations and extracting the lidar shorelines. The lidar research and development team included Abby Sallenger, Jeff List, Karen Morgan, Kristy Guy, Eric Nelson, Hillary Stockdon, and Kathy Weber. Rob Thieler worked closely with TPMC Environmental Services/Perot Systems Government Services to develop and improve the Digital Shoreline Analysis System (DSAS) code for shoreline-change measurement. Lindsey Kraatz, Heather Kaminsky, Jonathan Welker, and Brandon Owen provided tremendous assistance by geo-referencing and digitizing maps and preparing metadata. Betsy Boynton prepared many of the colorful illustrations, and Valerie Paskevich created the IMS. Critical reviews that greatly improved the technical content and clarity of the report were provided by John Haines, Cheryl Hapke, Jeff List, Bruce Richmond, Peter Ruggiero, Abby Sallenger, and Rob Thieler of the USGS; Spencer Rogers of North Carolina Sea Grant; Jim O'Connell of Woods Hole Oceanographic Institution Sea Grant; Steve Jones and Bob Mink of the Geological Survey of Alabama; Rebecca Beavers of the National Park Service; and Chris Parrish, Maryellen Sault, and Jason Woolard of the National Oceanographic and Atmospheric Administration (NOAA). 


\section{THE ROLE OF STATE AND FEDERAL GOVERNMENTS}

One reason for conducting this National Assessment of Shoreline Change is that there is no widely accepted standardized method of analyzing shoreline changes. Each state has its own data needs and coastal-zone management responsibilities (e.g., construction set-back lines, dune protection zones), and therefore each state uses a different technique and standard to compile shorelines and to calculate rates of shoreline movement. Consequently, calculated rates of shoreline change are inconsistent from state to state and cannot be compared directly. These inconsistencies were clearly demonstrated by the Federal Emergency Management Agency (FEMA) sponsored erosion studies (Crowell and Leatherman, 1999) that were used as a basis for evaluating erosion hazards (The Heinz Center, 2000). The USGS National Assessment of Shoreline Change represents the first time that shorelines from original data sources have been compiled and rates of shoreline change have been calculated on a national scale using internally consistent methods. The results of this analysis allow direct comparison of rates of change from one coastal segment to another and form the basis for future comparison of shoreline position.

Several federal agencies [USGS, FEMA, NOAA, U.S. Army Corps of Engineers (USACE)] have regulatory or administrative responsibilities pertaining to shorelines. Yet these responsibilities are quite different, requiring different approaches and offering substantial opportunities for cooperation. For example, the USACE is authorized and funded by Congress to report on the economic and environmental implications of shoreline change and the costs of erosion mitigation. Their National Shoreline Management Study (Stauble and Brumbaugh, 2003) is being conducted using existing shoreline data. The USGS will share data and information, such as the lidar-derived shoreline and rates of change, in support of their effort. NOAA has the mandate to establish the official shoreline boundary for the nation using tidal data. Their emphasis is on safe navigation and using the shoreline to generate nautical charts. NOAA also has a developing program ( $\mathrm{V}$ datum) that will greatly assist other agencies in establishing alternative shorelines for a variety of purposes where the official shoreline is inappropriate. Congress authorized and funded FEMA to report on the economic impact of erosion hazards on coastal communities and on claims to the National Flood Insurance Fund. To accomplish this, FEMA contracted state agencies and academic researchers to conduct a pilot study of erosion hazards that included shoreline-change data for limited geographic areas. The USGS is responsible for conducting research pertaining to coastal-change hazards including shoreline change, understanding the processes that cause coastal change, and developing models to predict future change. The USGS is the only government agency that has a dedicated program to monitor coastal change into the future using consistent methods nationwide. Such a program is critically important to assess national issues, such as the coastal impacts of sea-level rise.

\section{PRIOR NATIONAL AND SOUTHEAST ATLANTIC SHORELINE ASSESSMENTS}

The USACE (1971) conducted the first national assessment of coastal erosion that included the Southeast Atlantic region. That study identified areas of critical and non-critical erosion on the basis of economic development and potential for property loss, but rates of shoreline movement were not evaluated. Dolan and others (1985) conducted a comprehensive analysis of shoreline changes for the U.S. Their analysis was based on compilation of rates of shoreline change provided by other contributors and derived from their own studies of the middle Atlantic region. Rates of change were presented on maps, and the long-term trends of erosion and accretion were summarized in an accompanying text. There have been numerous local studies of shoreline movement in each of the Southeast Atlantic states. Rather than attempting to summarize all of these studies, Table 1 recognizes several statewide or sub-regional studies and provides appropriate references.

Since the work of Dolan and others (1985), methods of obtaining, analyzing, displaying, and storing shoreline data have improved substantially, and coastal change has continued. Furthermore, coastal scientists have not agreed on standard methods for analyzing and reporting shoreline changes, nor have they identified rigorous mathematical tests that are widely accepted for quantifying the change and associated errors. Consequently, there are critical needs for (1) a nationwide compilation of reliable shoreline data including the most recent shoreline position, and (2) a standardization of methods for obtaining and comparing shoreline positions and mathematically analyzing the trends.

\section{METHODS OF ANALYZING SHORELINE CHANGE}

\section{Compilation of Historical Shorelines}

Coastal scientists in universities and government agencies have been quantifying rates of shoreline movement and studying coastal change for decades. Before GPS and lidar technologies were developed, the most commonly used sources of historical shoreline position were NOAA Topographic Sheets (T-sheets, see Shalowitz, 1964) and aerial photographs. Ideally, extraction of shoreline position from these data sources involves geo-referencing and removing distortions from maps or aerial photographs, followed by digitizing shoreline posi- 
Table 1. Prior reports of quantitative regional analyses of long-term historical shoreline movement that used shorelines derived from T-sheets and/or aerial photographs.

\begin{tabular}{|l|l|}
\hline \multicolumn{1}{|c|}{ Region } & \multicolumn{1}{c|}{ References } \\
\hline Atlantic states & Dolan and others, 1985 ${ }^{\text {a }}$ \\
\hline East Florida & Clark, 1992; Dean and others, 1998 \\
\hline Georgia & Griffin and Henry, 1984; Langley and others, 2003 \\
\hline South Carolina & Anders and others, 1990 \\
\hline North Carolina & $\begin{array}{l}\text { Everts and others, 1983; Anders and others, 1990; } \\
\text { North Carolina Division of Coastal Management, 2004 }\end{array}$ \\
\hline
\end{tabular}

\footnotetext{
${ }^{a}$ Compilation of rates of change provided by authors and other investigators.
}

tion. Depending on coastal location, data source, and scientific preference, different proxies for shoreline position are used to document coastal change, including the high-water line [for discussion of the high-water line (HWL) see Shalowitz, 1964], wet-dry line, vegetation line, dune toe or crest, toe of the beach, cliff base or top, and the line of mean high water (MHWL).

In addition to deriving a modern shoreline from lidar data, the USGS National Assessment of Shoreline Change Project incorporates shoreline positions from pre-existing historical shoreline databases. Numerous organizations and individuals have provided the USGS with digital shoreline data (Table 2). To maintain consistency at a national scale, shorelines from four periods (mid- to late-1800s, 1920s-1930s, 1970s, and post-1998) were selected for analysis regardless of the number of shorelines available from existing data sets. Any remaining data gaps were filled using scans of historical T-sheets provided by the NOAA Vectorization Project.

For this report, the Southeast Atlantic region encompasses east Florida (north of Key Biscayne), Georgia, South Carolina, and North Carolina. Geographic locations or features referred to in the text are shown on Figure 1.

Shorelines were compiled for each state following the guidelines established for the four selected periods (mid- to late-1800s, 1920s-1940s, 1960s-1980s, and post-1997) as closely as possible. Table 3 lists the final range of years of the shorelines compiled for each period by state. A few notable exceptions include a second-period shoreline for North Carolina covering years up to 1946 and a third-period shoreline that covers years up to1988; a third-period shoreline for Florida beginning in 1967 and ending in 1980; and a complete third-period shoreline covering the 1960s for South Carolina. In North Carolina, from Cape Lookout to the Virginia border, available $\mathrm{T}$-sheet and aerial-photo surveys most closely matching the second-time period were completed in the 1940s. T-sheets most closely matching the third-time period for the same geographic region were completed in the 1980s. In Florida, the third-pe- riod shoreline incorporates two segments in Brevard County, north of Cape Canaveral, dated 1967 and 1969 and a segment in Nassau County dated 1980. In South Carolina, only a partial series of T-sheets representing time-period three were available for the 1970s, so a complete series from the early 1960s made a better alternative.

\section{Delineation of a Modern (lidar-derived) Shoreline}

The most recent shoreline used in this National Assessment (post-1997) was derived from lidar (Light Detection and Ranging) data. The USGS, in collaboration with NASA, has been using the NASA Airborne Topographic Mapper (ATM) to map coastal areas since 1997 (Krabill and others, 2000; Sallenger and others, 2003). The ATM surveys ground elevation using an elliptically rotating blue-green laser. GPS (global positioning system) positions and inertial navigation systems are used to correct for aircraft pitch, roll, and heading, providing ground elevations with accuracies of about $\pm 15 \mathrm{~cm}$ (Sallenger and others, 2003). The lidar surveys used to extract shorelines for this report were conducted between 1997 and 2000 (Table 3).

To compare with historical shorelines, an operational MHW shoreline was extracted from the lidar surveys using a method developed by Stockdon and others (2002) (Fig. 2). Shorelines were extracted from cross-shore profiles, which consist of bands of lidar data 2-4 $\mathrm{m}$ wide in the alongshore direction and spaced every $20 \mathrm{~m}$ along the coast. A leastsquares linear regression line is passed through the cluster of data that encompasses the operational MHW datum (Weber and others, 2005) and is limited to the seaward-sloping beach foreshore. The regression equation is then used to derive the horizontal intersection of the operational MHW datum with the profile, giving the shoreline position for that profile. Repeat- 
Table 2. Providers and original sources of historical shoreline data for each Southeast Atlantic Coast state.

\begin{tabular}{|c|c|c|c|}
\hline State & Organization & Original Data Source & Spatial Coverage \\
\hline \multirow{2}{*}{ Florida } & $\begin{array}{l}\text { Department of Environmental } \\
\text { Protection }\end{array}$ & NOAA T-sheets & Entire Coast \\
\hline & NOAA Coastal Services Center & Scanned NOAA T-sheets & Key Biscayne \\
\hline \multirow{2}{*}{ Georgia } & Georgia Southern University & Scanned NOAA T-Sheets & Entire Coast \\
\hline & NOAA Coastal Services Center & Scanned NOAA T-sheets & Entire Coast \\
\hline South Carolina & Coastal Carolina University & CERC Maps & Entire Coast \\
\hline \multirow{3}{*}{ North Carolina } & $\begin{array}{l}\text { DENR Division of Coastal } \\
\text { Management /NC State University }\end{array}$ & USACE aerial photographs & $\begin{array}{l}\text { Nags Head to Currituck } \\
\text { Lighthouse }\end{array}$ \\
\hline & $\begin{array}{l}\text { NOAA Coastal Services } \\
\text { Center/Information Manufacturing } \\
\text { Corporation }\end{array}$ & $\begin{array}{l}\text { Scanned or Geo- } \\
\text { referenced NOAA T-sheets }\end{array}$ & Entire Coast \\
\hline & USACE Duck FRF Library & CERC Maps & $\begin{array}{l}\text { Cape Hatteras to Virginia } \\
\text { border; South Carolina border to } \\
\text { Shallotte Inlet }\end{array}$ \\
\hline
\end{tabular}

ing this procedure at successive profiles $20 \mathrm{~m}$ apart generates a continuous shoreline.

To determine the operational MHW elevation, the Southeast Atlantic region was divided into nine subregions (Weber and others, 2005). For each subregion, the operational MHW elevation represents an average of MHW elevations from individual open-ocean or near open-ocean tide gauges. A list of tide gauges and MHW elevations used in each subregion is presented in Table 4. The lidar-extracted MHW shoreline is not the same as a MHW shoreline surveyed by a licensed land surveyor. This is because the operational MHW elevation used for the lidar shoreline is an average of the MHW elevations at several tide gauges. Furthermore, the lidar-extracted shoreline is intended only as a reference feature for measuring shoreline change. It is not intended to establish legal boundaries.

\section{Geographic Information System (GIS) Procedures}

Digital shorelines for each selected period were compiled as ESRI ArcView shapefiles and a quality assessment was performed. Shoreline gaps for each period were identified and NOAA T-sheet indexes were used to determine T-sheet availability for those areas. T-sheets were then requested from NOAA and received as scanned TIF images or as geo-referenced images.
T-sheets were geo-referenced using Erdas Imagine geographic imaging software by placing at least six well-spaced ground-control points (GCPs) on selected T-sheet graticules in geographic coordinates. Some T-sheets produced before 1930 required additional coordinate transformation information from NOAA to convert from the United States Standard Datum (USSD) to the North American Datum of 1927 (NAD27). The datum transformation was applied to T-sheet graticule coordinates prior to georeferencing. Total Root Mean Square (RMS) error for the georeferencing process was maintained below 1 pixel, which is approximately $4 \mathrm{~m}$ at a scale of 1:20,000 and approximately $1.5 \mathrm{~m}$ at a scale of 1:10,000. Typically, the resulting RMS was much lower than one pixel. The geo-referenced T-sheets were displayed in ArcView and shorelines were digitized. Completed shoreline vectors were then converted to the Universal Transverse Mercator (UTM) projection using the North American Datum of 1983 (NAD83).

Shorelines from all sources were merged to produce a single shoreline for each of the four time periods by state. Final shorelines were coded with six attribute fields (ID, Type, Date, Description, Source, and Accuracy) to calculate shoreline-change rates using the Digital Shoreline Analysis System (DSAS). The attributes include the original survey year in the Date field and the source of the data in the Source field. 


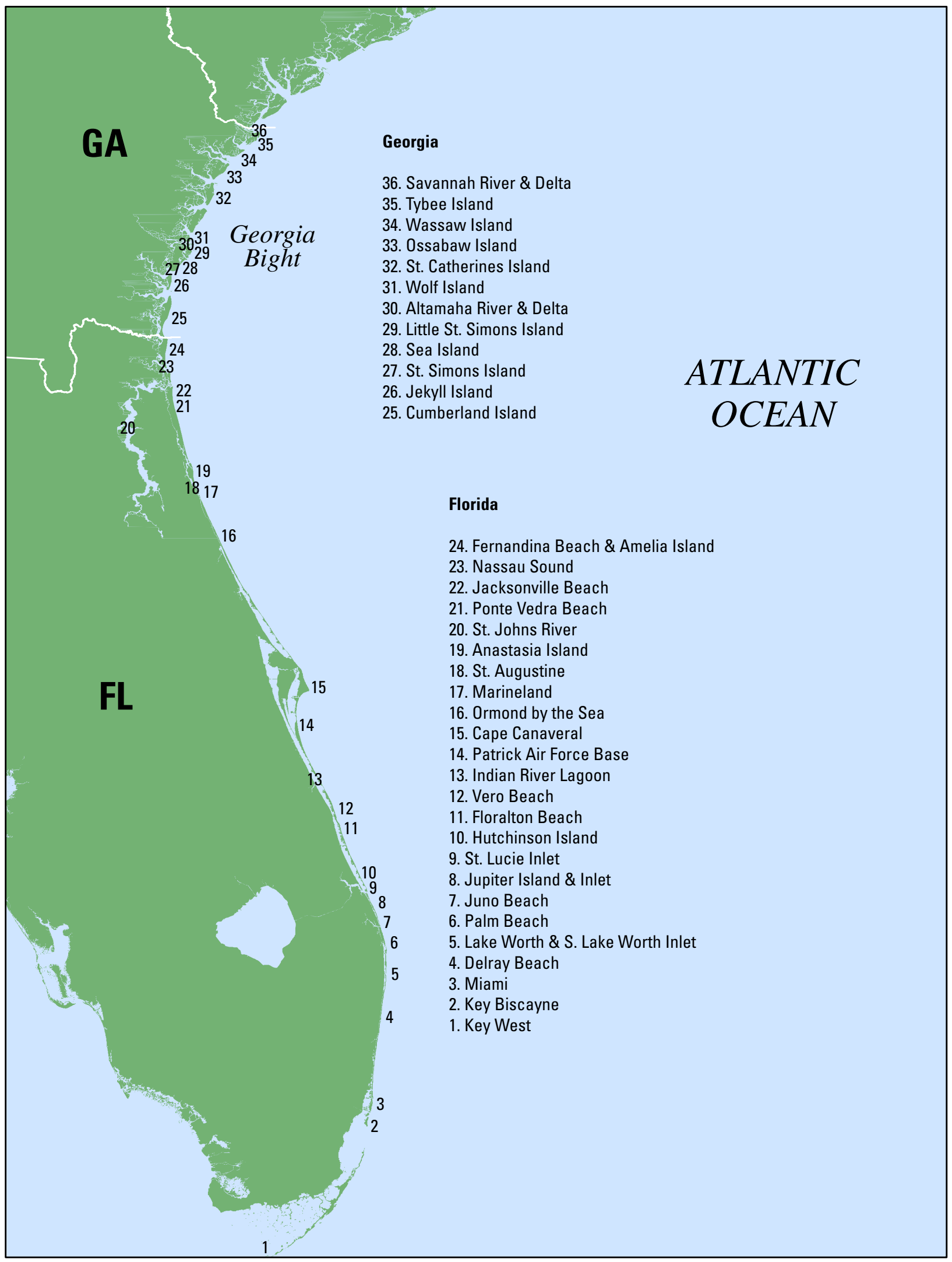

Figure 1A. Index map of the Southeast Atlantic region showing locations in Florida and Georgia. 


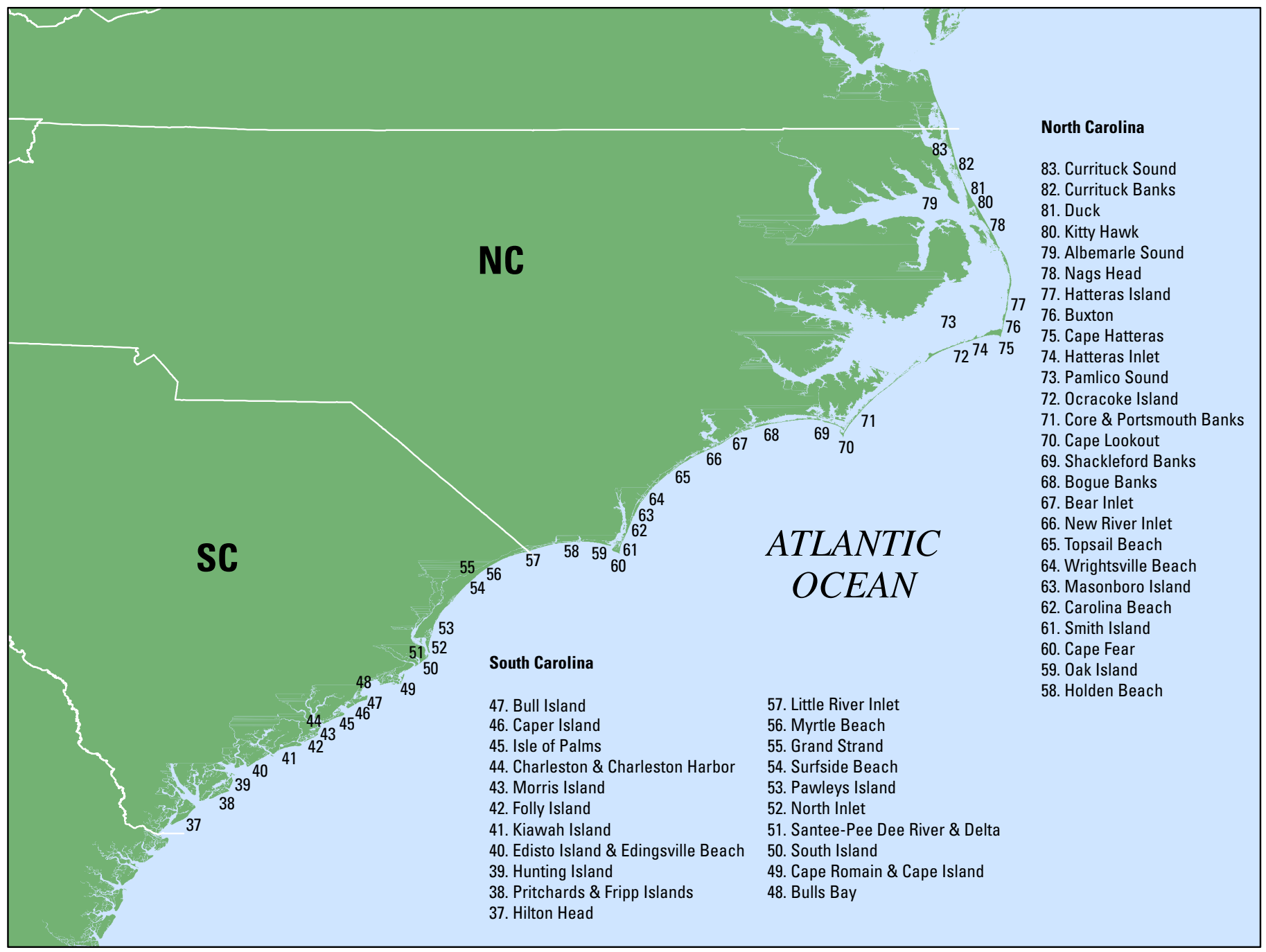

Figure 1B. Index map of the Southeast Atlantic region showing locations in South Carolina and North Carolina.

\section{Calculation and Presentation of Rates of Change}

Rates of long-term shoreline change were generated with the Digital Shoreline Analysis System (DSAS) version 2.0 (Thieler and others, 2005), an ArcView extension. The extension is designed to lead a user efficiently through the major steps of shoreline change analysis. This extension to ArcView contains three main components that define a baseline, generate orthogonal transects at a user-defined separation along the coast, and calculate rates of change (linear regression, endpoint rate, average of rates, average of end points, jackknife). The extension utilizes Avenue code to develop transects and rates and uses the Avenue programming environment to automate and customize the user interface.

Baselines were constructed seaward of, and parallel to, the general trend of the four shorelines. Using DSAS, transects were spaced $50 \mathrm{~m}$ apart. Transects were manually eliminated to prevent calculation of rates in areas where less than four shorelines were intersected. Fewer than four shorelines can result from one or more of the following conditions (Fig. 3): 1) an inlet eliminated one or more of the shorelines, 2) shoreline segments were missing (data gaps), 3) a barrier island migrated laterally (no overlap of shorelines and/or misrepresentation of rates), and 4) a shoreline disappeared over time.

Long-term rates of shoreline change were calculated at each transect using linear regression applied to all four shoreline positions from the earliest (1800s) to the most recent (derived from lidar). Linear regression was selected because it has been shown to be the most statistically robust quantitative method when a limited number of shorelines are available (Crowell and others, 1997). It is also the most commonly applied statistical technique for expressing shoreline movement and estimating rates of change (Crowell and Leatherman, 1999). Short-term rates of shoreline change were calculated using the endpoint method comparing the 1970s and most recent (lidar-derived) shoreline positions. Long-term rates and 
Table 3. Dates of compiled shorelines for selected periods.

\begin{tabular}{|l|c|c|c|c|}
\hline \multirow{2}{*}{ State } & \multicolumn{3}{|c|}{ Selected Time Periods } \\
\cline { 2 - 5 } & $\begin{array}{c}\text { PERIOD 1 } \\
\text { mid- to late-1800s }\end{array}$ & $\begin{array}{c}\text { PERIOD 2 } \\
\mathbf{1 9 2 0 s - 1 9 4 0 s}\end{array}$ & $\begin{array}{c}\text { PERIOD 3 } \\
\mathbf{1 9 6 0 s - 1 9 8 0 s}\end{array}$ & $\begin{array}{c}\text { PERIOD 4 } \\
\text { post-1997 }\end{array}$ \\
\hline Florida & $1851-1884$ & $1923-1930$ & $1967-1980$ & 1999 \\
\hline Georgia & $1857-1870$ & $1920-1925$ & $1971-73$ & 1999 \\
\hline South Carolina & $1852-1875$ & $1920-1926$ & $1962-1964$ & 2000 \\
\hline North Carolina & $1849-1873$ & $1925-1946$ & $1970-1988$ & 1997 \\
\hline
\end{tabular}

short-term rates of shoreline change, as defined here, are used throughout the report. Both long-term and short-term rates of shoreline change calculated for each transect (50- $\mathrm{m}$ alongshore spacing) were color coded according to class interval with green colors indicating accretion and red colors indicating erosion. The shoreline-change rates and individual shoreline-data layers were compiled into an ArcIMS, or Arc Internet Map Server, viewable at http://coastalmap.marine.usgs.gov/.

\section{Shoreline Definitions and Beach Alterations that Influence Rates of Change}

\section{Shoreline Definitions}

Inclusion of a lidar-derived shoreline represents a new approach to the investigation of shoreline change. The three pre-lidar historical shorelines come from topographic maps and aerial photographs that use the HWL as the shoreline proxy. For more than 150 years, the HWL has served as the authoritative shoreline because it could be visually identified in the field. With advanced technologies such as GPS and lidar, it is possible to define the shoreline on the basis of an elevation or a tidal datum, such as MHW. Changing the shoreline definition from a physical feature that is uncontrolled in terms of an elevation datum to a shoreline defined by an elevation has important implications with regard to inferred changes in shoreline position and calculated rates of change.

Morton and others (2004) compiled published and unpublished data to evaluate the horizontal and vertical differences in HWL determined from beach profiles, aerial photographs, or GPS surveys, and the MHWL derived from beach profiles, GPS surveys, or lidar surveys (Table 5). The HWL and MHWL positions were established at the same time, or within a few weeks of one another, at multiple sites around the U.S. where the beach and wave characteristics are diverse. Comparing these HWL and MHWL positions assumes that the observed offsets are entirely artifacts of shoreline definition and are not related to actual changes in the beach profile between the survey dates. This is a relatively safe assumption, considering the short intervals between surveys or the knowledge that a particular shoreline segment is relatively stable.
Table 5 shows that average absolute horizontal and vertical offsets between the HWL and MHWL range from a few meters to more than $50 \mathrm{~m}$, and vertical offsets can be as much as $2 \mathrm{~m}$. Most of the horizontal offsets are less than $20 \mathrm{~m}$, and most of the vertical offsets are less than $1 \mathrm{~m}$. Offsets are greatest on relatively flat beaches where high waves produce high wave runup (southwest Washington). Conversely, offsets are least where beaches are relatively steep and wave runup is low (west coast of Florida). Because breaking waves run up on the beach, the MHWL is most commonly seaward of the HWL (Morton and Speed, 1998). For the data analyzed by Morton and others (2004), the MHWL was seaward of the HWL at more than $90 \%$ of the transects (Table 5). Because a MHWL shoreline is used for the latest period, this nearly systematic horizontal offset between the HWL and the MHWL could cause shoreline positions and calculated rates of change to imply slower erosion, a change from erosion to accretion, or faster accretion depending on actual changes at a given site.

\section{Human Activities}

Attempts to stabilize the shore can also greatly influence the rates of shoreline change. Activities such as beach nourishment or emplacement of shoreline-stabilization structures tend to alter coastal processes, sediment transport, and shoreline position. For example, beach nourishment artificially causes rapid, temporary shoreline accretion. Depending on the frequency of beach nourishment, the placement of large volumes of sand on the beach will bias the rates of observed shoreline change toward accretion or stability, even though the natural beach, in the absence of nourishment, may be eroding.

Valverde and others (1999) prepared a summary of identifiable beach-nourishment projects in the Southeast Atlantic region before 1996. These records were used to identify shoreline segments that had been influenced by beach nourishment. Additional information regarding beach nourishment was provided by Ralph Clark of the Florida Department of Environmental Protection. Only projects that pre-date the lidar shoreline were included. There is no distinction made between large-volume, continuous projects and small-volume, finite projects. Differentiating between natural rates of erosion and the influences of beach nourishment is difficult because experiments have not 

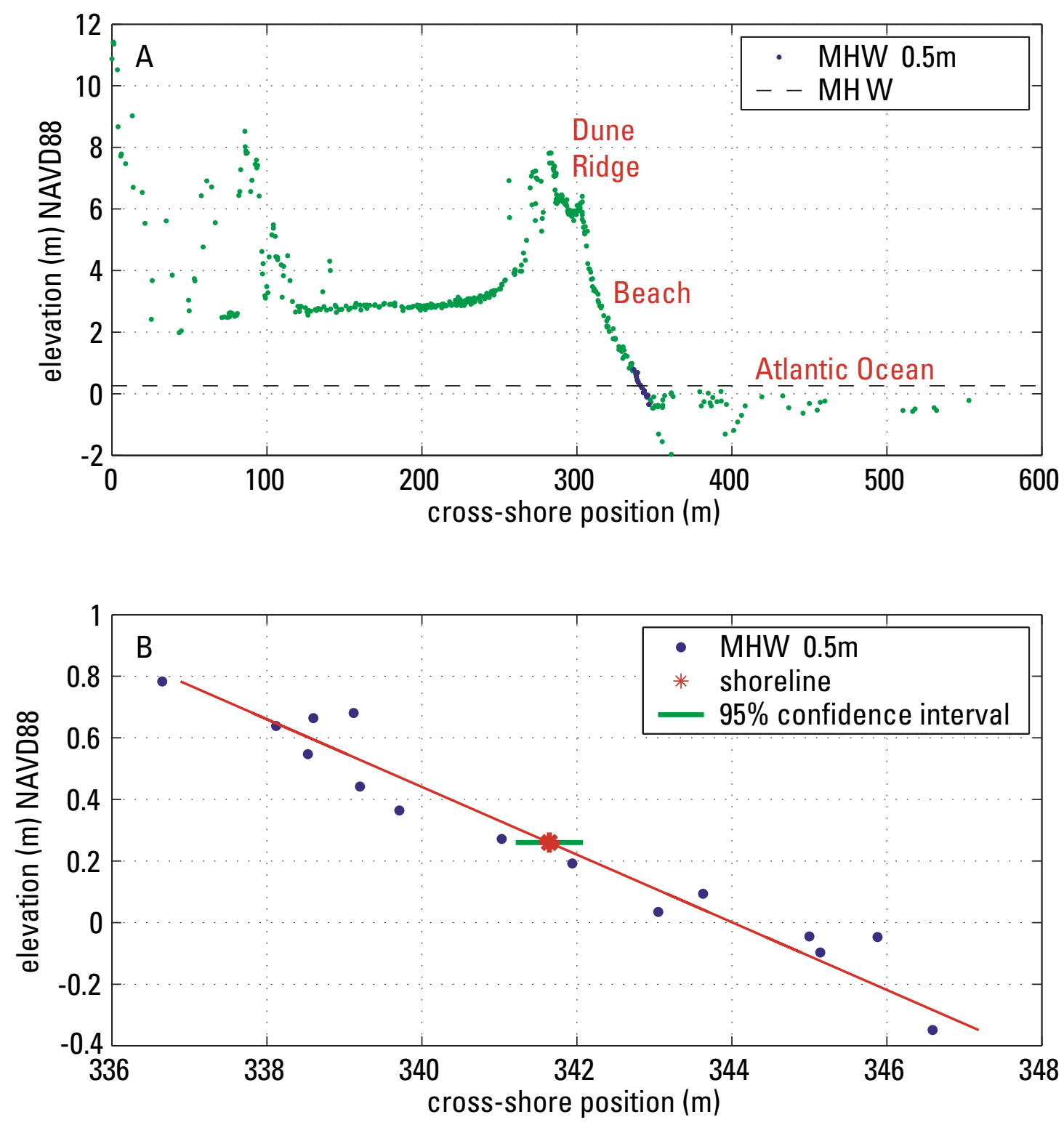

Figure 2. Example of a lidar profile from September 26, 1997 at Kitty Hawk, North Carolina, for (A) the entire cross-shore region and (B) an expanded view of the foreshore region. (A) Laser returns off of the water's surface are seen as the noisy signal seaward of $x=350 \mathrm{~m}$. Bold symbols indicate data points within \pm 0.5 $\mathrm{m}$ of the operational MHW datum. (B) The asterisk marks the cross-shore position of the shoreline on the foreshore. The horizontal error bar represents the $95 \%$ confidence interval about the estimate. From Stockdon and others (2002).

been conducted to address this issue specifically. In addition, available data may be inadequate because there are not enough shoreline positions immediately before, after, and between nourishment projects. Human responses to coastal erosion in each state, including beach nourishment and emplacement of structures, are discussed in more detail in a later section.

\section{Reliability of the Results}

Documented trends and calculated rates of shoreline change are only as reliable as: (1) measurement errors that determine the accuracy of each shoreline position, (2) sampling errors that account for the variability of shoreline position, and (3) statistical errors (variability) associated with compiling and comparing shoreline positions. Anders and Byrnes 
Table 4. List of tide-gauge measurements used to calculate mean high-water elevation (Weber and others, 2005).

\begin{tabular}{|l|c|c|}
\hline \multicolumn{1}{|c|}{ Site Name } & $\begin{array}{c}\text { MHW above NAVD88 } \\
(\mathbf{m})\end{array}$ & $\begin{array}{c}\text { Average of MHW } \\
(\mathbf{m})\end{array}$ \\
\hline Miami Beach, FL & 0.03 & \\
Haulover Pier, FL & 0.06 & \\
North Miami Beach, FL & 0.04 & 0.07 \\
Lauderdale-By-The-Sea, FL & 0.11 & \\
Hillsboro Inlet, FL & 0.07 & \\
Lake Worth Pier, FL & 0.09 & \\
Fort Pierce, FL & 0.00 & 0.28 \\
Vero Beach, FL & 0.13 & 0.45 \\
\hline Daytona Beach Shores, FL & 0.28 & 0.52 \\
\hline Saint Augustine Beach, FL & 0.45 & 0.68 \\
\hline Saint Augustine Beach, FL & 0.45 & \\
Jacksonville Beach, FL & 0.58 & 0.75 \\
\hline Little Talbot Island, FL & 0.66 & \\
Saint Simons Island, GA & 0.71 & \\
\hline Braddock Point, SC & 0.81 & \\
Port Royal Plantation, SC & 0.75 & \\
Edisto Beach, SC & 0.69 & \\
\hline Isle of Palms Pier, SC & 0.53 & \\
Pawleys Island Pier, SC & 0.50 & \\
Garden City Pier, SC & 0.46 & \\
Springmaid Fishing Pier, SC & 0.55 & \\
Yaupon Beach, NC & 0.49 & \\
\hline Wilmington Beach, NC & 0.36 & \\
Atlantic Beach, NC & 0.37 & \\
\hline Cape Hatteras Fishing Pier, NC & 0.24 & \\
Duck, NC & 0.27 & \\
Sandbridge Beach, VA & 0.31 & \\
Virginia Beach, VA - 2 & 0.21 & \\
Virginia Beach, VA - 1 & 0.29 & \\
\hline
\end{tabular}

(1991), Crowell and others (1991), Thieler and Danforth (1994), Moore (2000), and Daniels and Huxford (2001), provided general estimates of the typical measurement errors associated with mapping methods and materials for historical shorelines, registry of shoreline position relative to geographic coordinates, and shoreline digitizing. The largest errors were positioning errors of $\pm 10 \mathrm{~m}$, which were attributed to scales and inaccuracies in the original surveys (T-sheets and aerial photographs). However, the influence of large shoreline position errors on long-term rates of change can be reduced because the period of analysis is so long (>100 yrs). Stockdon and others (2002) provided estimates of GPS positioning errors $( \pm 1 \mathrm{~m})$ and regression errors $( \pm 1.5 \mathrm{~m})$ associated with shorelines derived from lidar data.

Estimates of the maximum measurement errors for this study are provided in Table 6 to show how each error contributes to uncertainty in the shoreline position and in the rates of change. A total shoreline position error (Esp)(Equation
1) incorporates all of the measurement errors by taking the square root of the sum of the squares of: georeferencing error $(\mathrm{Er})$, digitizing error $(\mathrm{Ed}), \mathrm{T}$-sheet survey error $(\mathrm{Et})$, shoreline proxy offset (Eo), and lidar position error (El). Georeferencing error represents the elected maximum acceptable RMS error for T-sheets at a scale of 1:20,000 in this study. We assume data from outside sources conform to similar standards. The georeferencing error is applied to the historical shorelines only. Digitizing error reflects the maximum digitizing error specified in past studies (Anders and Byrnes, 1991; Crowell and others, 1991; Moore, 2000). The digitizing error is applied to the historical shorelines only. The maximum T-sheet survey error for time periods 1 and 2 (1800s and 1920s-1930s), determined by Shalowitz (1964), incorporates all of the errors associated with the mapping process, including distance to rodded points, plane-table position, and identification of the HWL. Because more recent T-sheets, including time-period three (1970s), are derived from aerial photographs, the T-sheet survey error is 


\section{A Inlet Openings}

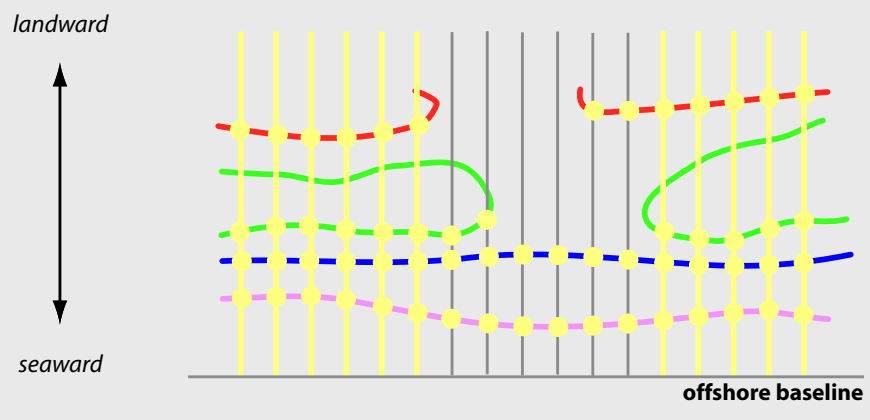

\section{Barrier Migration}

landward
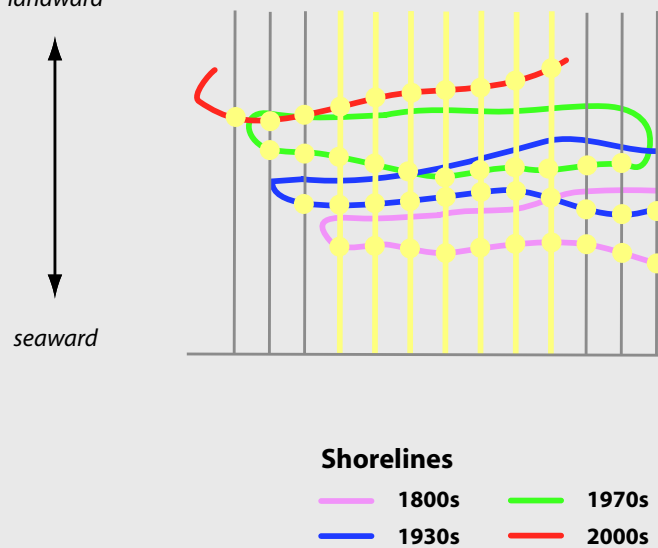

offshore baseline
B Missing Data

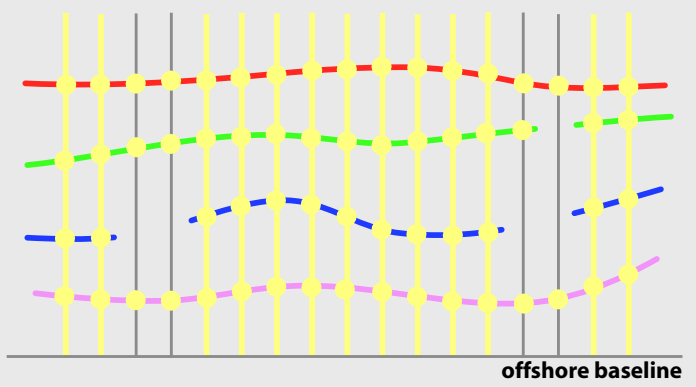

\section{Shoreline Loss}

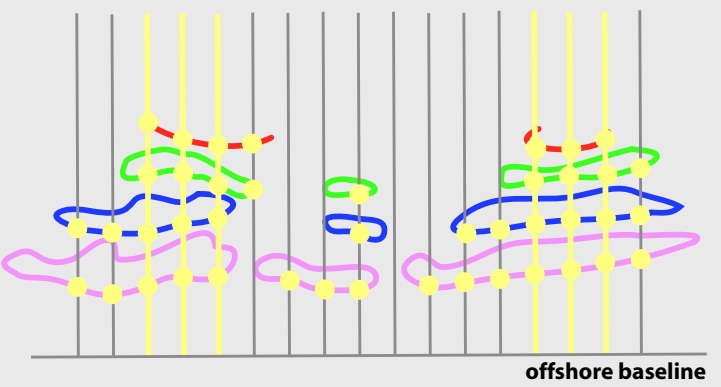

Transects

used for calculation transect/shoreline

eliminated intersection

Figure 3. Examples of common conditions where transects are eliminated in the absence of four shoreline intersections.

substantially less (Daniels and Huxford, 2001). The shorelineproxy offset reflects the maximum horizontal offset between high-water and mean high-water shorelines in the Southeast Atlantic region (see Table 5). The offset error pertains only to the lidar-derived shoreline. Lidar position error reflects the maximum error associated with the derivation of a lidar shoreline (Stockdon and others, 2002). The lidar position error is applied only to the lidar-derived shoreline. Thus, total shoreline-position error is expressed by:

A separate $\mathrm{E}_{\mathrm{sp}}$ can be calculated for each period.

$$
E_{s p}=\sqrt{E_{r}^{2}+E_{d}^{2}+E_{t}^{2}+E_{o}^{2}+E_{l}^{2}}
$$

Sampling errors relating to the local short-term variability of true shoreline positions (Morton, 1991; Douglas and Crowell, 2000) are less well known. Temporally dense data are required to evaluate short-term shoreline variability result- ing from seasonal cycles and from rapid storm erosion and subsequent recovery. Moreover, most datasets include some apparent shoreline movement caused by changes in water level (HWL) and not changes in sediment volume (Morton, 1991). Lack of reliable high-frequency data regarding short-term variability of true shoreline position at most coastal sites limits the ability to quantify and incorporate the associated uncertainty into the overall shoreline position uncertainty. An exception is the 20-year record of beach profiles surveyed by the USACOE at Duck, N.C. Using 460 shoreline positions from the Duck profile data, Barton and others (2003) showed that the envelope (range) of shoreline positions even around a relatively stable shoreline was about $\pm 20 \mathrm{~m}$.

Linear regression is the most commonly applied statistical technique for expressing shoreline movement and estimating rates of change (Crowell and Leatherman, 1999). Linear regression assumes linear behavior, which technically is incorrect (Morton, 1991; Barton and others, 2003), but is adequate for a 
Table 5. Absolute horizontal and vertical differences between high-water and mean high-water shorelines (Morton and others, 2004).

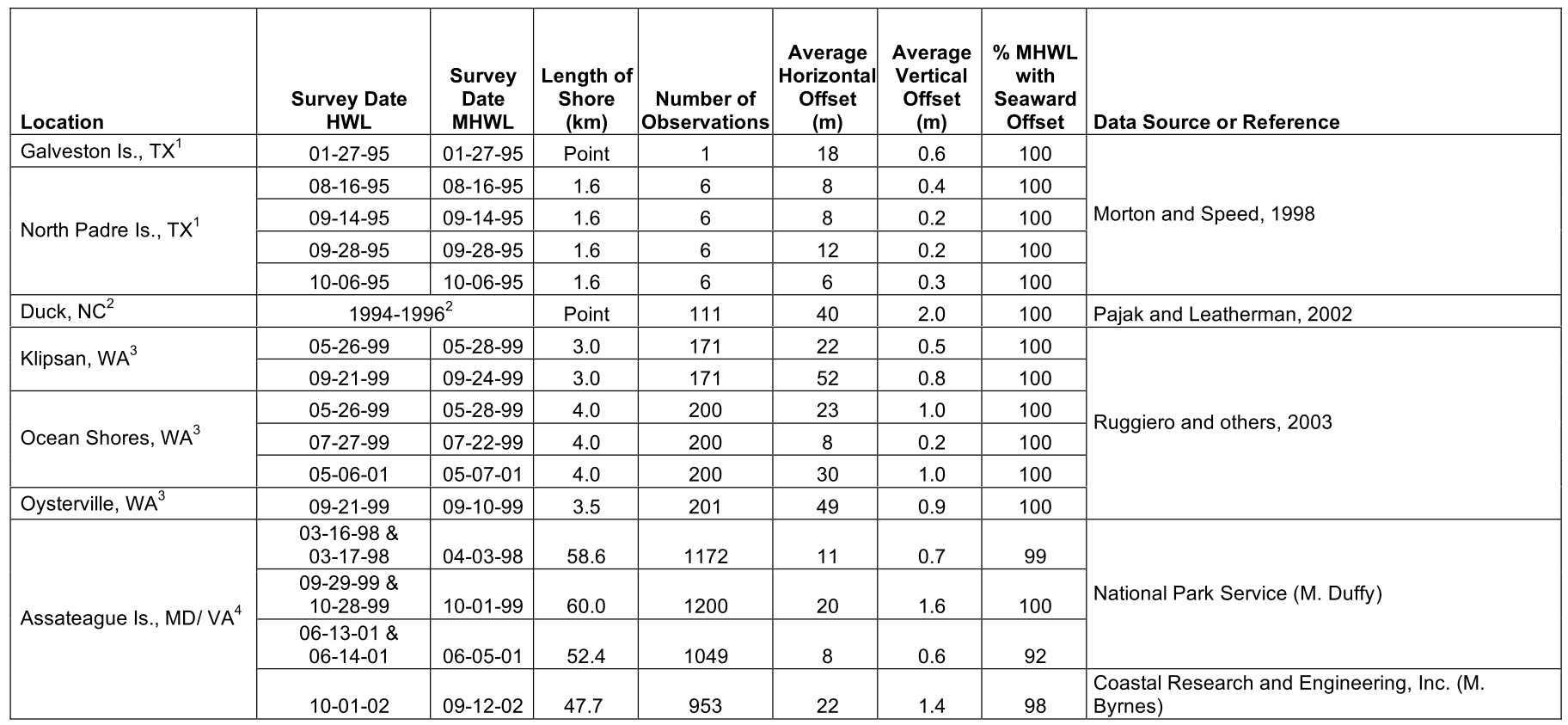

${ }^{1}$ Simultaneous measurement of HWL and MHWL at beach profiles coordinated with tide-gauge measurements.

${ }^{2}$ Video-camera projections of HWL for 111 days during a three-year period and MHWL from generalized beach profiles.

${ }^{3}$ Nearly simultaneous aerial photographs (HWL) and GPS surveys (MHWL).

${ }^{4}$ Nearly simultaneous GPS (HWL) and lidar surveys (MHWL).

first approximation. Because linear regression fails to recognize the potential for temporal differences in trend (trend reversals) and accelerations or decelerations (Morton, 1991; 1996), average trends and rates of shoreline change in this study were calculated for long-term (entire period) and short-term (most recent) time scales. Long-term rates of shoreline change were determined at each transect by taking the slope of the regression line applied to all four shoreline positions. The resulting rate is reported in units of $\mathrm{m} / \mathrm{yr}$ (Table 7). Uncertainties for the long-term rates ( \pm values in Table 7) are also reported in units of $\mathrm{m} / \mathrm{yr}$. The reported uncertainties represent a $90 \%$ confidence interval for the slope of the regression line. This means with
90\% statistical confidence that the true rate of shoreline change falls within the range defined by the reported value plus or minus the error value. The variability around the trend line reflects both measurement and sampling errors.

Field observations and prior studies of shoreline movement within each state in the Southeast Atlantic region (Table 1) suggest that the trends and relative rates of change presented in this study are reasonably accurate. Reliability of the mapped results increases as both the persistence of the trend and rates of change increase. Stated another way, confidence in the analytical results is greatest where the rates of shoreline erosion or accretion are high, the trend has persisted for decades, and

Table 6. Maximum estimated measurement errors for Southeast Atlantic shorelines.

\begin{tabular}{|c|c|c|c|c|}
\hline \multirow{2}{*}{ Measurement Errors $(\mathbf{m})$} & \multicolumn{5}{|c|}{ Time Period $^{\boldsymbol{*}}$} \\
\cline { 2 - 5 } & $\mathbf{1}$ & $\mathbf{2}$ & $\mathbf{3}$ & $\mathbf{4}$ \\
\hline Georeferencing error $\left(\mathrm{E}_{\mathrm{r}}\right)$ & 4 & 4 & 4 & na \\
\hline Digitizing error $\left(\mathrm{E}_{\mathrm{d}}\right)$ & 1 & 1 & 1 & na \\
\hline T-sheet survey error $\left(\mathrm{E}_{\mathrm{t}}\right)$ & 10 & 10 & 3 & na \\
\hline Shoreline proxy offset $\left(\mathrm{E}_{\mathrm{o}}\right)$ & na & na & na & 22 \\
\hline Lidar position error $\left(\mathrm{E}_{\mathrm{l}}\right)$ & na & na & na & 1.5 \\
\hline & & & & \\
\hline Total shoreline position error $\left(\mathrm{E}_{\mathbf{s p}}\right) \mathbf{( m )}$ & 10.8 & 10.8 & 5.1 & 22.1 \\
\hline
\end{tabular}

*Time periods: $1=1800$ s; $2=1920$ s-1940s; 3=1960s-1980s; 4=post-1997; na = not applicable 
Table 7a. Long-term shoreline-change trends, derived from linear regression rates using four shorelines.

\begin{tabular}{|c|c|c|c|c|c|c|c|c|}
\hline \multirow[b]{2}{*}{ State } & \multirow[b]{2}{*}{$\begin{array}{l}\text { Number of } \\
\text { Transects }\end{array}$} & \multirow{2}{*}{$\begin{array}{c}\text { Mean } \\
\text { Shoreline } \\
\text { Change Rate } \\
(\mathrm{m} / \mathrm{yr})\end{array}$} & \multirow[b]{2}{*}{$\%$ Erosion } & \multicolumn{2}{|c|}{ Erosion Rates (m/yr) } & \multirow[b]{2}{*}{$\%$ Accretion } & \multicolumn{2}{|c|}{ Accretion Rates (m/yr) } \\
\hline & & & & Max & Mean & & Max & Mean \\
\hline Florida & 11,288 & $0.2 \pm 0.6$ & 39 & $-5.5 \pm 5.9$ & -0.5 & 61 & $14.3 \pm 16.3$ & 0.6 \\
\hline Georgia & 2,566 & $1.0 \pm 2.7$ & 35 & $-9.4 \pm 4.0$ & -1.5 & 65 & $13.9 \pm 10.2$ & 2.4 \\
\hline South Carolina & 4,921 & $-0.5 \pm 3.0$ & 51 & $-13.0 \pm 18.8$ & -2.8 & 49 & $16.9 \pm 21.2$ & 1.8 \\
\hline North Carolina & 8,849 & $-0.7 \pm 1.3$ & 70 & $-7.6 \pm 2.0$ & -1.4 & 30 & $10.7 \pm 11.8$ & 1.0 \\
\hline
\end{tabular}

Table 7b. Short-term shoreline-change trends, derived from end-point rates using two recent shorelines.

\begin{tabular}{|c|c|c|c|c|c|c|c|c|}
\hline \multirow[b]{2}{*}{ State } & \multirow[b]{2}{*}{$\begin{array}{l}\text { Number of } \\
\text { Transects }\end{array}$} & \multirow{2}{*}{$\begin{array}{c}\text { Mean } \\
\text { Shoreline } \\
\text { Change Rate } \\
\text { (m/yr) }\end{array}$} & \multirow[b]{2}{*}{$\%$ Erosion } & \multicolumn{2}{|c|}{ Erosion Rates (m/yr) } & \multirow[b]{2}{*}{$\%$ Accretion } & \multicolumn{2}{|c|}{ Accretion Rates (m/yr) } \\
\hline & & & & Max & Mean & & Max & Mean \\
\hline Florida & 11,547 & 0.7 & 29 & -20.1 & -0.7 & 71 & 80.4 & 1.2 \\
\hline Georgia & 2,661 & 1.3 & 40 & -23.9 & -2.9 & 60 & 22.1 & 4.2 \\
\hline South Carolina & 5,312 & -0.6 & 39 & -21.2 & -4.1 & 61 & 38.8 & 1.8 \\
\hline North Carolina & 9,661 & 0.0 & 59 & -57.0 & -1.8 & 41 & 69.7 & 2.5 \\
\hline
\end{tabular}

the trend is consistent for long stretches of coast. On the other hand, confidence in the absolute results decreases where the shoreline is relatively stable and the rates of change are low. This is because minor differences in historical or lidar shoreline positions can alter substantially the regression line and the calculated results. Data confidence also decreases in areas where frequent trend reversals occur.

Advanced technology such as GPS and lidar can better constrain shoreline positions, reduce the methodological errors, and improve the accuracy (reduce the error) for future shoreline analyses. Establishing a datum-based shoreline (lidar derived MHWL) as the standard for comparison provides the ability to perform an error analysis that is both quantitative and meaningful, in terms of its application. In the future, each digital MHWL shoreline could be presented with an accompanying error bar that would define the alongshore envelope of confidence. Subsequent shorelines and associated confidence envelopes would provide a more precise basis for determining the statistical significance of observed shoreline change. Unfortunately, the use of lidar or any other shoreline mapping technology will still require distinguishing between short-term variability in shoreline position and the long-term trend of shoreline change.

\section{GEOMORPHOLOGY OF THE SOUTHEAST ATLANTIC REGION}

The Southeast Atlantic region is a low-lying area that consists of a variety of coastal features including mainland shores, estuaries and lagoons, barrier islands and capes, tidal inlets, and delta plains (Fig. 4). The physical characteristics and geologic framework of each of these features partly determine the trends and rates of shoreline movement and related coastal changes of the region.

\section{Southeast Atlantic Mainland Shores}

The Southeast Atlantic coast consists mainly of barrier islands, but there are some segments where the ocean meets the mainland shore without an intervening estuary or lagoon. In Florida, extensive stretches of sandy mainland shore are exposed to ocean waves north of Miami to Delray Beach, from Juno Beach to Jupiter Inlet, from north of Ormond by the Sea to south of Marineland, and from the St. Johns River to Ponte Vedra Beach. There are no ocean-fronting mainland shores in Georgia, but in South Carolina, the Grand Strand including Myrtle Beach is a sandy mainland shore that extends from North Inlet to Little River Inlet. Sandy mainland shores occupy much of the southern North Carolina coast between Little River Inlet and Oak Island. Only the Atlantic Intracoastal Waterway separates the ocean shore from the mainland along much of this segment.

\section{Estuaries and Lagoons}

Most large coastal estuaries or sounds bordering the Southeast Atlantic coast are drowned river valleys that have remained unfilled because the rivers emptying into the estuaries are transporting very little sediment. Charleston Harbor, South Carolina and Albemarle Sound, North Carolina are good examples of estuaries. The estuaries generally are oriented perpendicular to the Atlantic shoreline, whereas lagoons are parallel to the shoreline. Some lagoons are named properly, such as Indian River Lagoon, Florida, whereas some are named sounds such as Pamlico Sound, and Currituck Sound, North Carolina. The moderately wide coastal lagoons, which formed when the uplands between the river valleys were flooded by rising sea level, separate the barrier islands from the mainland. Narrow coastal lagoons, like many of those in Florida, are formed by rivers that flow parallel to the shore. Some former lagoons are 


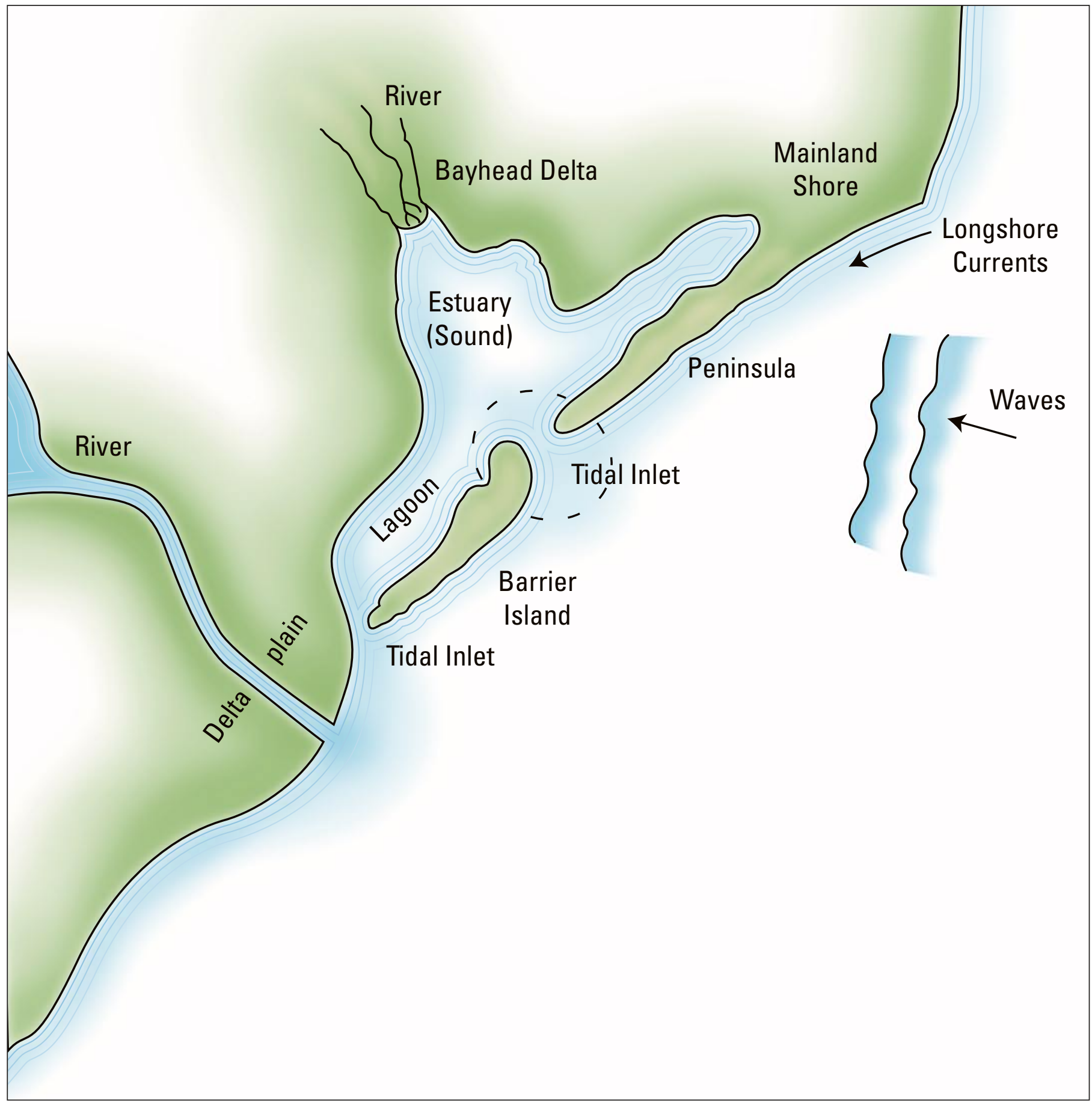

Figure 4. Common coastal landforms of the Southeast Atlantic region.

filled with extensive marshes, such as those along the Georgia coast.

Estuarine and lagoon shores account for the longest stretches of eroding shoreline in the Southeast Atlantic region. They are also the most complex in terms of land loss because they have different orientations and relief, and they cut across sediments with different elevations and resistance to erosion.
Estuarine and lagoon shores can be composed of sand, shell, or mud, and they can form low beaches, tall bluffs, or marshes. Analyses of shoreline changes in estuaries and lagoons are not included because the focus of this report is on the Southeast Atlantic open-ocean shoreline. 


\section{Barrier Islands and Capes}

\section{Origin and Evolution of Barriers and Capes}

The origins and related morphologies of barrier islands can influence shoreline movement because the thicknesses and volumes of sand stored in the barriers are related to the processes that formed them. Barrier islands commonly form the outer fringes of low-lying coastal plains throughout the world. As their name implies, they are surrounded by water and are separated from the adjacent mainland by lagoons, bays, or marshes and from neighboring islands by tidal inlets. Barrier islands are long and narrow mounds of sand deposited by waves and wind over millennia. In general, they are produced by long-term submergence of the low-gradient coast. Three independent mechanisms (Fig. 5) have been proposed for the origins of barrier islands: (1) dune drowning (McGee, 1890), (2) spit elongation (Gilbert, 1885), and (3) shoal emergence
(De Beaumont, 1845). Each mechanism explains the origin of some barriers (Hoyt, 1967), but no single cause explains the origins of all barriers (Schwartz, 1971).

Barrier islands can form by dune drowning (Fig. 5A) when a relative rise in sea level partly inundates a mainland ridge of coastal dunes. The rising water encompasses the sand dunes along the beach and eventually floods the seaward sloping coastal plain between the dunes and upland, forming a lagoon.

Spit elongation (Fig. 5B) refers to lateral barrier extension along the prevailing trend of the beach. Sand transported along the coast by longshore currents is deposited on the flanks of headlands or at the downdrift ends of existing barrier islands. Spit elongation is a widely observed process whereby barriers are originally constructed across embayments, forming lagoons, or previously formed barriers are enlarged in a downdrift direction. Recurved beach ridges are diagnostic field evidence of spit accretion. This type of barrier formation gener-

\section{A. Dune Drowning}

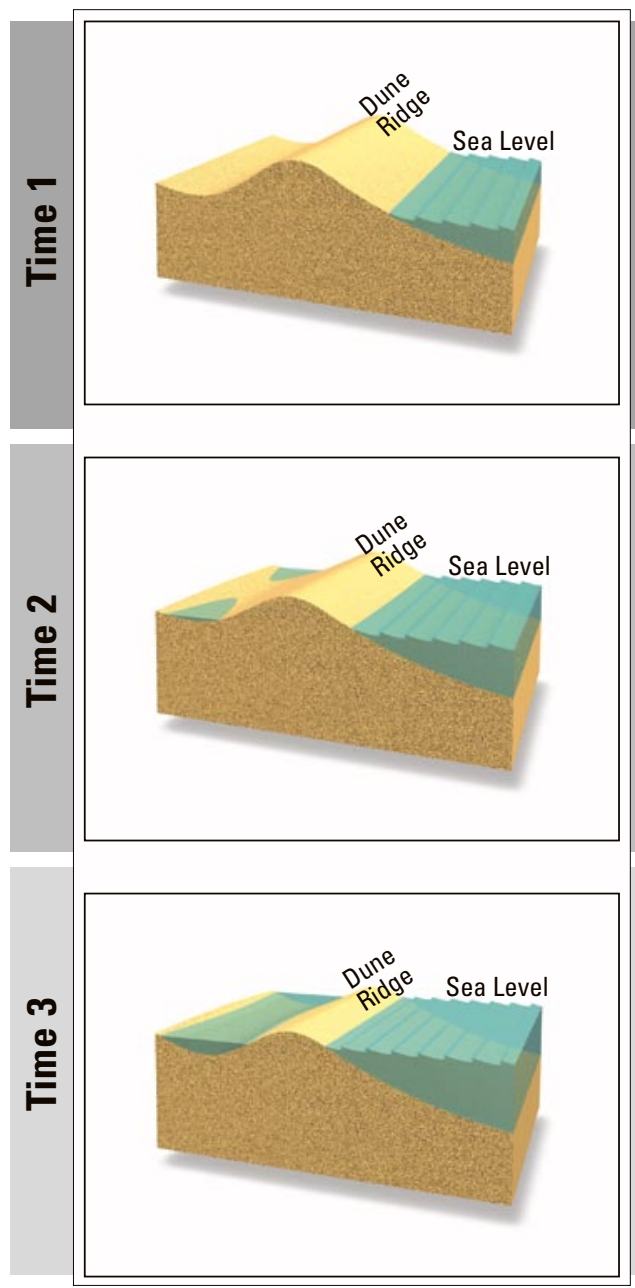

B. Spit Elongation

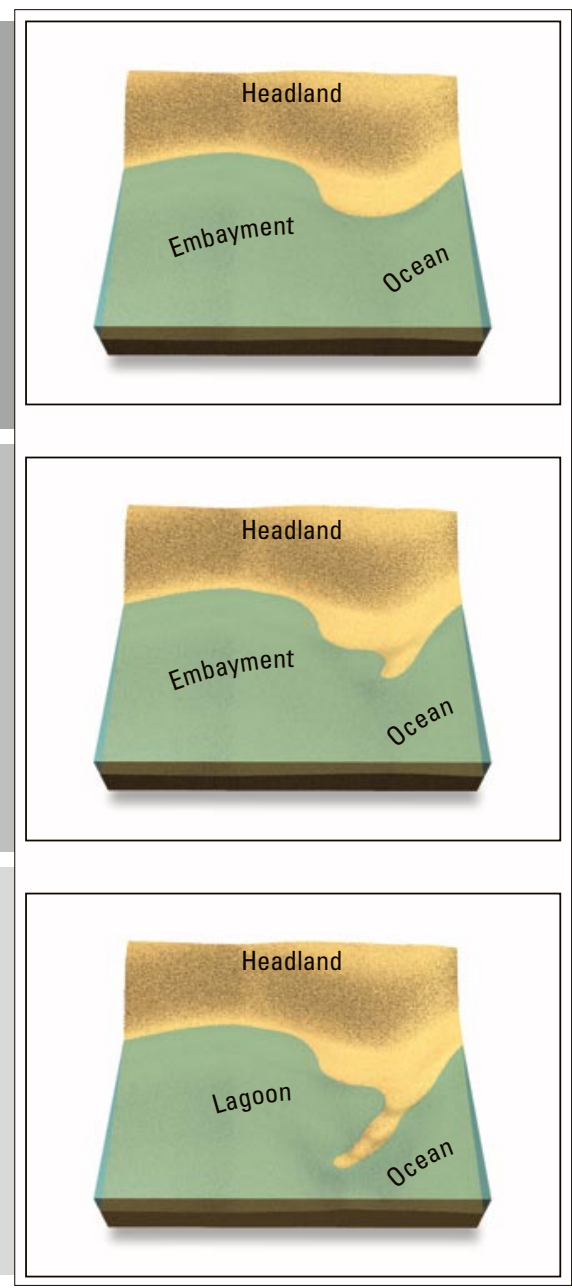

\section{Shoal Emergence}

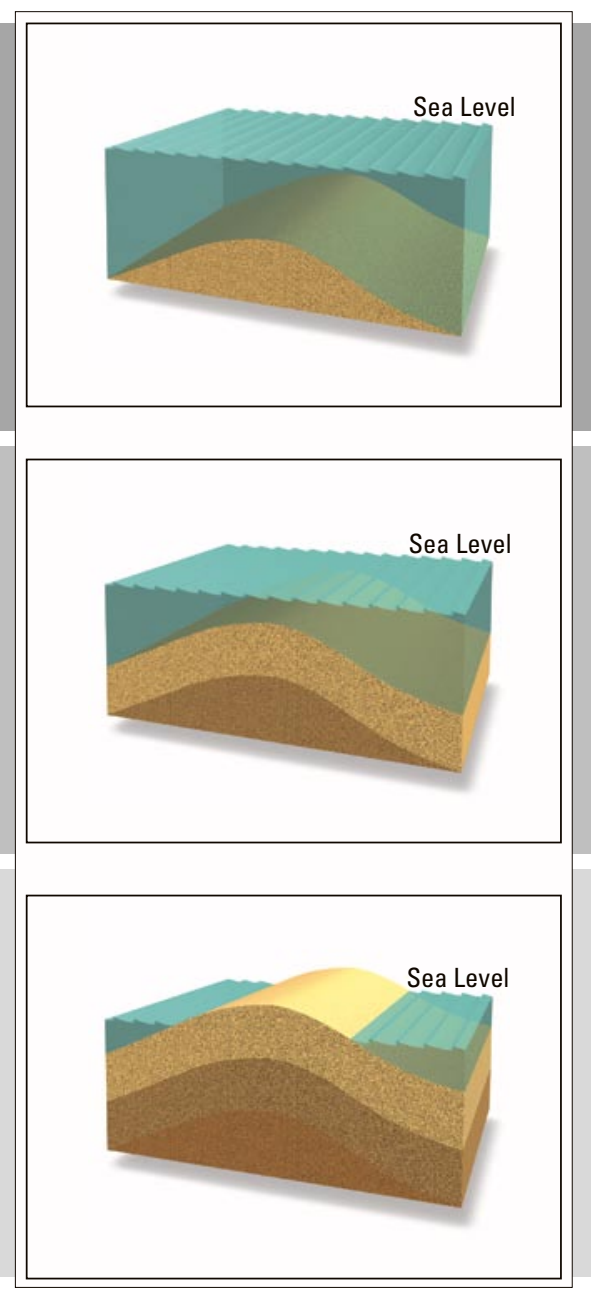

Figure 5. Conceptual diagram showing possible origins of barrier islands. 
ally occurs under stable sea-level conditions and/or a surplus of sand supply.

Shoal emergence (Fig. 5C) involves the upward growth of a submerged bar where sand is supplied by erosion and redistribution of sediment on the sea floor. The vertical accumulation of sand eventually causes the bar to rise above the ocean level so that the emergent bar forms a barrier island. Shoal emergence is aided by a slight lowering of relative sea level, such as after a storm, and it also requires a local surplus of sand to maintain the barrier.

Many barrier islands in the Southeast Atlantic region, such as Amelia Island, Florida, Ossabaw Island and Wassaw Island, Georgia, Isle of Palms and Kiawah Island, South Carolina, and Bogue Banks, North Carolina, originally migrated across the continental shelf and then began to grow seaward when the rise in sea level slowed about 5,000 years ago (Fig. 6). Some barriers have grown laterally as a result of spit elongation (St. Catherines Island, Georgia), and other barriers formed around an island core of older barrier deposits left over from a previous time when sea level was at about the same level as today (Amelia Island, Florida, Jekyll Island and Cumberland Island, Georgia). Still other barriers, such as St. Simons Island and Tybee Island, Georgia, and South Island, South Carolina, have formed in conjunction with delta progradation at the mouths of the Altamaha, Savannah, and Santee-Pee Dee Rivers, respectively (Brown, 1977; Hayes, 1994).

There are five prominent cuspate forelands or capes along the Southeast Atlantic coast (Hoyt and Henry, 1971). From south to north they are Cape Canaveral, Florida, Cape
Romain, South Carolina, and Cape Fear, Cape Lookout, and Cape Hatteras, North Carolina. Common characteristics of the capes are a general triangular shape, seaward protrusion beyond the general shoreline trend, abrupt changes in shoreline orientation, and multiple divergent beach ridges indicating that they have been sites of long-term sand deposition. The North Carolina capes also are oriented such that the updrift (northern or eastern) limb is exposed to strong winter waves and is eroding, whereas the downdrift (southern or western) limb is more sheltered from storm waves and is accreting (Moslow and Heron, 1994). A broad field of shoals extending offshore from each cape also indicates that the shoals have been zones of long-term accumulation of sand transported along the beaches. Hoyt and Henry (1971) reviewed the proposed origins of capes (large-scale oceanographic circulation, convergence of reversing longshore currents, wave refraction, structural uplift) and concluded that capes of the Southeast Atlantic region are probably associated with former rivers and developed as a result of ancestral delta deposits on the continental shelf. Later, Blackwelder and others (1982) demonstrated that antecedent topography on the shelf formed by outcrops of indurated strata largely controlled the positions of Cape Fear and Cape Lookout, North Carolina. It is possible that the offshore geologic framework also anchors other cape locations, and their growth and morphological changes are a result of seasonal reversals in longshore currents (Hayes, 1994).

Today, the highest elevations and largest sand dunes along the Southeast Atlantic coast are present on the sand-rich progradational (seaward-building) barrier islands and capes such

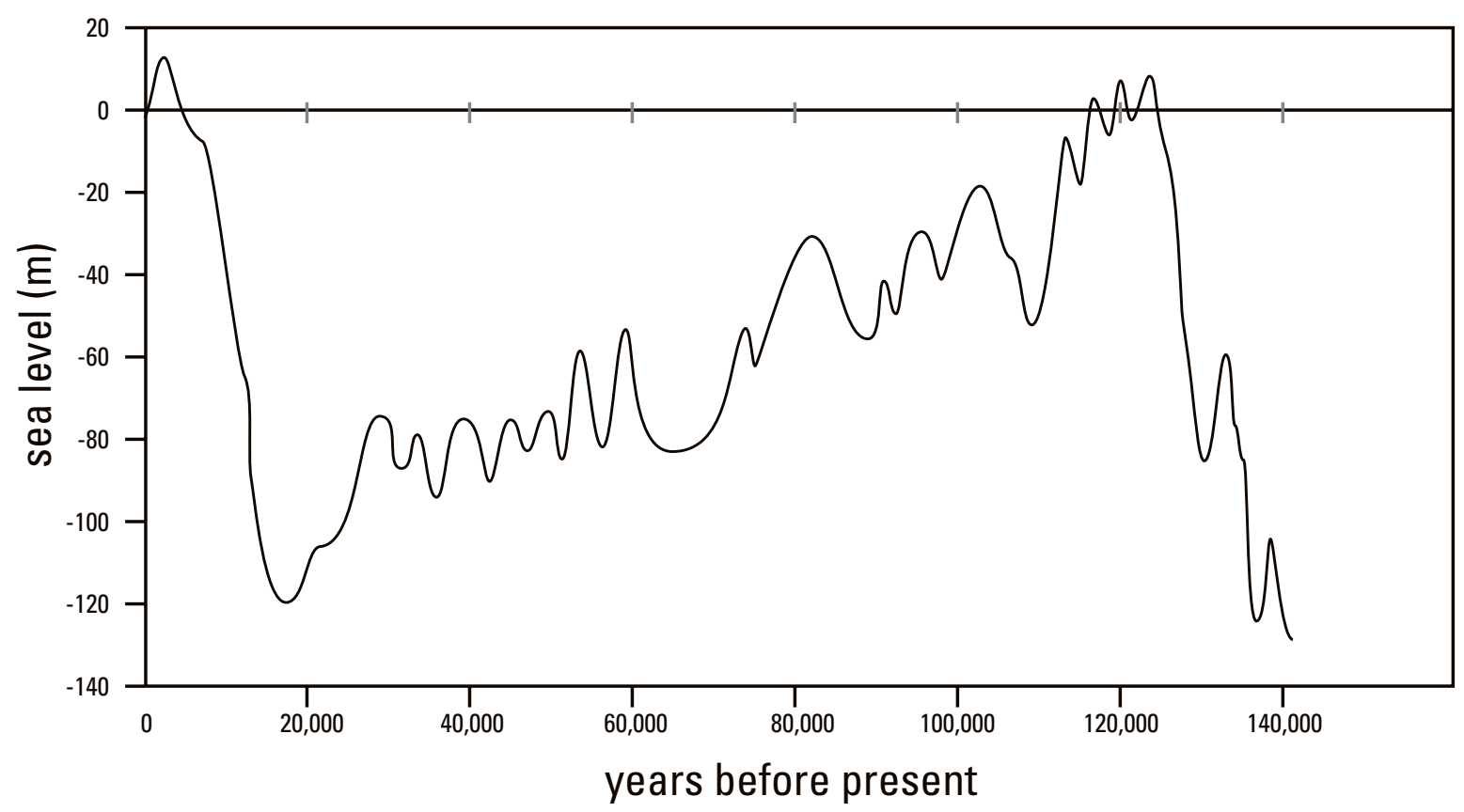

Figure 6 . Sea-level curve during the past 140,000 years that depicts the general magnitude and timing of sealevel changes in the Atlantic Ocean. Modified from Chappell and others (1996). 
as Cape Canaveral, Florida, Little St. Simons Island, Georgia, Kiawah Island, South Carolina, and Currituck Banks, North Carolina. Much of the coastal sand that was washed ashore as sea level reached its present position is stored in these highprofile barriers (Fig. 7), and they typically have lower erosion rates because of the abundant sand. However, at some coastal locations, the volume of sand stored in the dunes may contribute to beach erosion (Fig. 8). Migrating and landward retreating barriers, such as Hutchinson Island, Florida, Edingsville Beach, South Carolina, and Core Banks, North Carolina, typically have higher erosion rates because they are located away from major sources of sand.

\section{Morphologies of Southeast Atlantic Barrier Islands}

Barrier islands make up more than two-thirds of the Southeast Atlantic shore. Each of the barriers can be classified as either high-profile or low-profile (Fig. 7) depending on the elevations and morphology of the island. The height and continuity of these elevations determine the ability of the barriers to
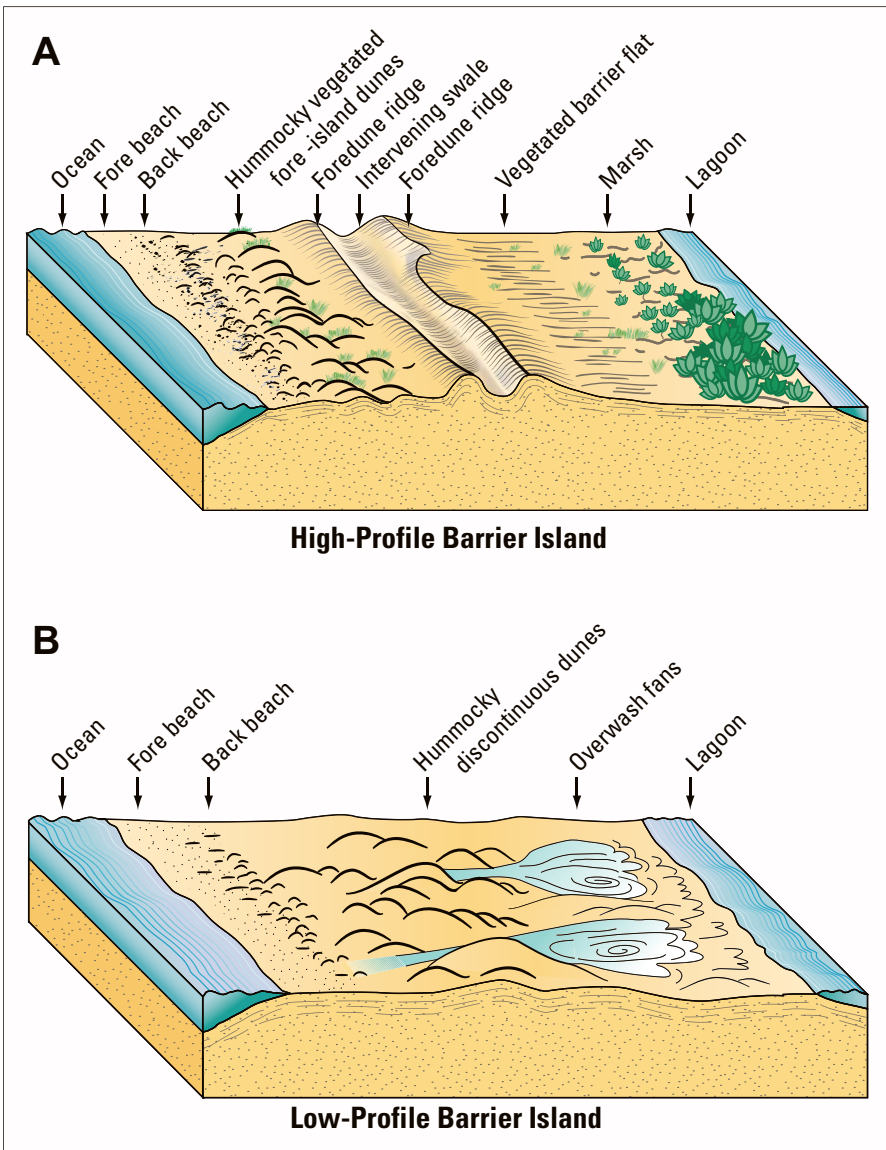

Figure 7. Geomorphological characteristics of high- and lowprofile barrier islands. Modified from White and others (1978). withstand storm-surge flooding and overwash. The origins and profiles of the barriers also partly determine the stability of the shoreline.

Low-profile barriers, such as Hutchinson Island, Florida, Morris Island and islands around Cape Romain, South Carolina (Fig. 9), and Core-Portsmouth Banks and northern Hatteras Island, North Carolina, are typically narrow and characterized by discontinuous or narrow frontal dunes that are inundated by extreme storm surges. This makes the barrier vulnerable to overwash during storms. Overwash can create channels and fans that transfer sand from the ocean onto the barrier or into the adjacent lagoon. Barrier upbuilding, another common process of barrier evolution, is a response to a rise in relative sea level, and the transfer of sand from the ocean to the lagoon is a mechanism by which the barrier migrates landward and still retains its general shape and sand volume. Island migration is enhanced if there is a deficit in the sand supply or if there is a rapid rise in relative sea level. However, if the rate of sea-level rise is too great, then the barrier island may be drowned and left as a submerged sand shoal on the continental shelf.

High-profile barriers, such as Amelia Island, Florida, Wassaw Island, and Little St. Simons Island, Georgia (Fig. 10), Capers Island, Bull Island, and Kiawah Island, South Carolina, and minor segments of the barrier islands of North Carolina near Kitty Hawk are the result of abundant sand supply for thousands of years. These barriers are typically wide and have continuous, well-vegetated dunes. The high elevations effectively block storm surges and prevent island overwash, even during the most severe storms. In addition, enough sand is stored in the dunes that they are able to withstand prolonged erosion without being breached, which would allow flooding of the barrier core. However, flooding of high-profile barriers can occur from the lagoon side or from the ocean through artificial breaks in the dune ridge, such as beach-access roads or areas where dunes have been destroyed by coastal construction.

\section{Tidal Inlets}

Tidal inlets are the primary channels separating the barrier islands (Fig. 4). They also allow the exchange of water and migration of marine organisms between the Atlantic Ocean and adjacent estuaries and lagoons. In Georgia and southern South Carolina, more water flows out of the tidal inlets than flows in during a tidal cycle. This asymmetry, referred to as ebb-dominated flow, is a result of abundant freshwater inflow supplied by rivers in the adjacent estuaries. The ebb-flow asymmetry also contributes to the formation of large ebb shoals that store vast quantities of sand on the seaward margins of the inlets (Hayes, 1994). Periodic cycles of sand storage and release from the ebb-delta shoals throughout the Southeast Atlantic coast have had profound influences on the patterns of shoreline erosion and deposition adjacent to the inlets. 


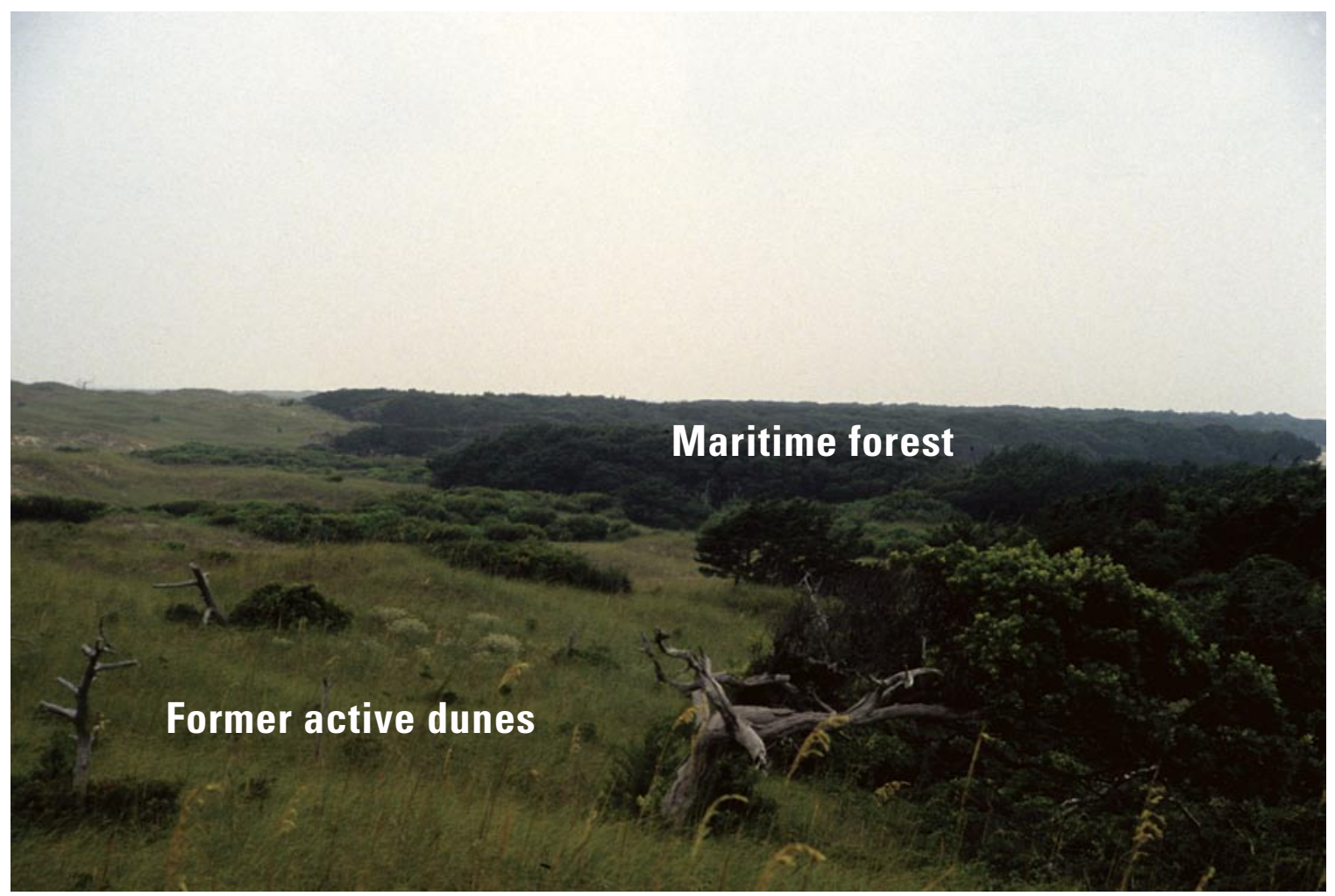

Figure 8. Former active sand dunes on Shackleford Banks, North Carolina, that partly buried a maritime forest, may contribute to erosion by removing sand from the beach. Dunes are activated when the stabilizing vegetation is destroyed either as a result of natural causes (droughts, grass fires) or as a result of human activities (off-road vehicles, overgrazing, construction).

The strength and relative proportion of tidal and wave energy greatly influences the morphology of barrier islands and lagoons, and the number and spacing of tidal inlets (Nummedal and others, 1977; Hayes, 1994). For example, in Florida and northern North Carolina, where tidal range is relatively low and subordinate to wave energy, wave-dominated barrier islands and adjacent lagoons are long and narrow, and tidal inlets are few, small, and widely spaced. In contrast, where tidal range is high, as in Georgia and southern South Carolina, tide-dominated barrier islands are short and wide, and tidal inlets are numerous and closely spaced.

Shorelines near unstabilized inlets are commonly sites of high variability and rapid erosion due to channel and shoal migration and high current velocities. Long-term rates of change and their associated uncertainties at sites near inlets can be useful in conveying the variable nature of the shoreline and the derived risks from a coastal-hazards perspective. For this study, some of this variability may be minimized in the rates and uncertainties around inlets because of the decision to maintain data consistency by deleting transects in cases where less than four shorelines were present.

Large inlets are used for navigation into and out of the coastal bays and adjacent ports. These navigable inlets have been modified for maintenance of deep-draft channels, and many of the channels are lined by long rock jetties. Where they are unmodified, sand banks and beaches line the inlets. Several man-made inlets through Southeast Atlantic barrier islands have altered water-circulation patterns, longshore currents, and littoral drift and have locally caused or contributed to both beach erosion and accretion (Dean and O'Brian, 1987). Some of the artificial inlets in Florida include Government Cut opened in 1905 near Miami and Bakers Haulover Cut opened in 1925 also near Miami, and South Lake Worth Inlet opened in 1927. In North Carolina, New Drum Inlet on Core Banks was opened in 1972.

Long, narrow microtidal barrier-island segments that have low relief (maximum dune elevations of less than $2 \mathrm{~m}$ ) and that are far from existing tidal inlets are susceptible to breaching and new inlet formation during extreme storms (Morton, 2002). Inlet formation may occur when fast-moving hurricanes tracking near the coast produce storm surges that exceed the dune heights. When there is insufficient time for lagoon water levels to respond to elevated open-ocean water levels, a hydraulic head can be created, driving flows landward across the narrow barrier and incising channels. The North Carolina coast has been the site of numerous historical inlet openings or reactiva- 


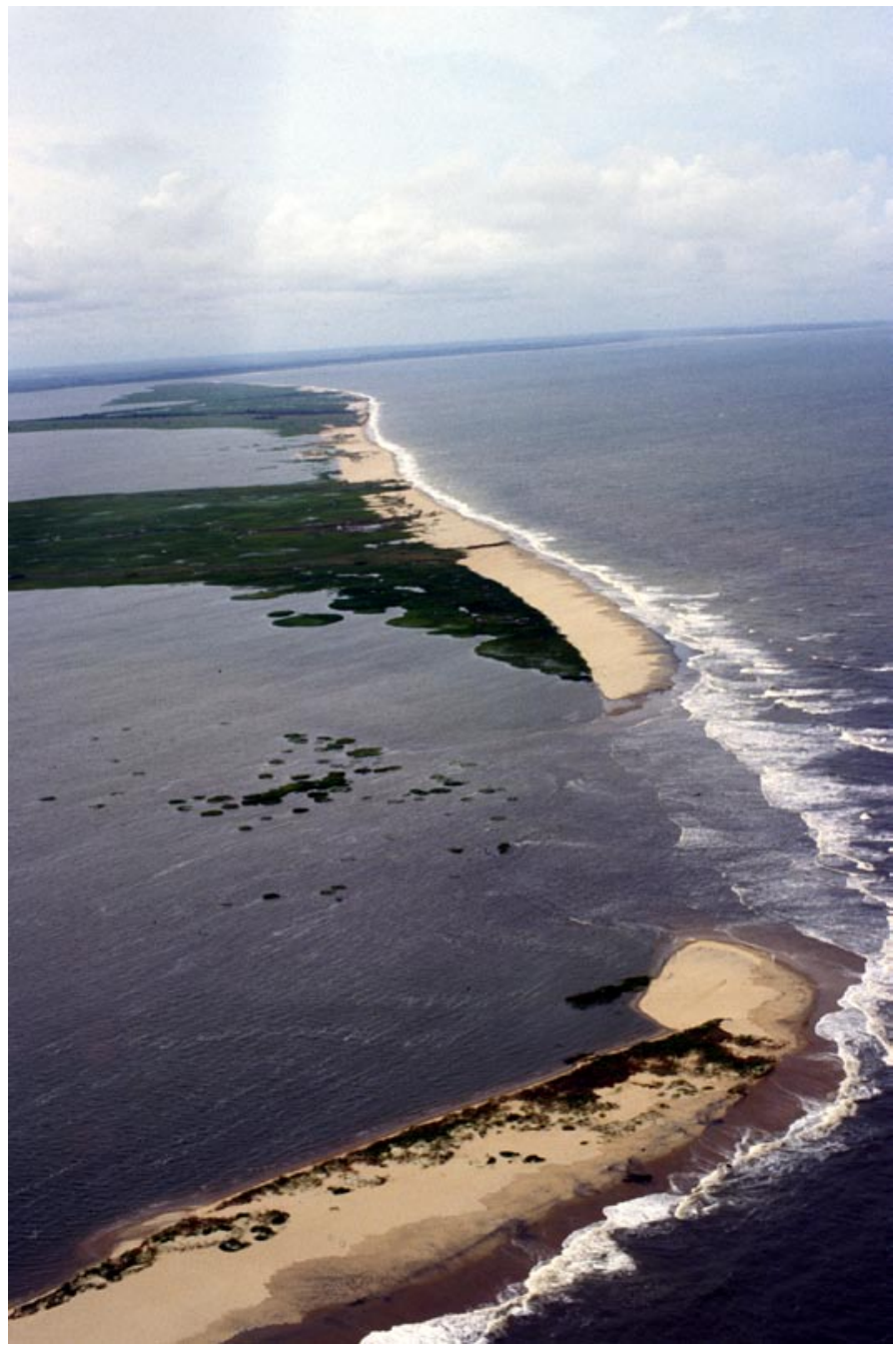

Figure 9. Low, narrow barrier islands, such as those around Cape Romain, South Carolina, are overwashed frequently during storms.

tion of closed inlets (Fisher, 1962; Cleary and Hosier, 1979) and is particularly vulnerable to this extreme-storm response.

Some tidal inlets opened during storms may remain open for long periods. For example, in North Carolina, a hurricane in 1933 opened Barden Inlet at Cape Lookout. The 1962 Ash Wednesday storm opened an inlet at Buxton, and Hurricane Isabel (2003) opened two inlets near Hatteras. These latter inlets were quickly closed by the North Carolina Department of Transportation. A northeaster in 1986 cut through Folly Island, South Carolina, and Hurricane Hugo in 1989 cut a new inlet through Pawleys Island, the barrier just north of North Inlet. Barrier breaching commonly reoccurs where narrow spits or peninsulas attach to headlands. Breaching is also common where substantial downdrift inlet migration has over time produced a low barrier segment and a long ebb channel that is hydrodynamically inefficient.

\section{Delta Plains}

The Altamaha River in Georgia, the Savannah River at the Georgia/South Carolina border, and the Santee-Pee Dee River in South Carolina are the only fluvial systems of the Southeast Atlantic region that have built deltas into the Atlantic Ocean. The relatively small drainage areas, low topographic relief, and low sediment yields of rivers in Florida prevent delta construction along its Atlantic coast. In addition, most rivers draining the east coast of Florida are located landward of and parallel to the barriers forming narrow "lagoons" that separate the barriers from the mainland. The major rivers in North Carolina empty into estuaries rather than into the Atlantic Ocean (Meade, 1982).

Ocean shores of the Altamaha delta have both eroded and accreted in historical time (Griffin and Henry, 1984). The shores of Wolf Island eroded, whereas Little St. Simon Island mostly accreted. Long-term historical shoreline changes of the Savannah delta have been mixed (Griffin and Henry, 1984). Wassaw Island rotated counter-clockwise, eroding on the north end and accreting on the southern end. Little Tybee Island and Tybee Island exhibited segments of both erosion and accretion.

Despite being the largest delta on the east coast of the United States and having sufficient sediment supply for delta construction in the past, some shores of the Santee-Pee Dee delta have eroded, whereas others have accreted. Artificial reductions in sediment supply related to dam construction and river diversion are largely responsible for rapid shoreline erosion along the Santee-Pee Dee delta (Hayes and others, 1994).

\section{GEOLOGIC HISTORY AND SETTING}

River deltas, barrier islands, and marshes built the broad coastal plain bordering the Southeast Atlantic coast during two periods when sea level was relatively high. The highest coastal plain elevations were formed about 130,000 years ago during a late Pleistocene interglacial period when sea level was about 6 to $8 \mathrm{~m}$ higher than today (Fig. 6). The lower coastal-plain elevations associated with modern marshes and barrier islands formed when sea level reached its present position about 5,000 years ago. Between these periods, the shape and origin of the present Southeast Atlantic coast was greatly influenced by changes in sea level due to expansion and melting of continental glaciers. The present-day shape of the Southeast Atlantic coast, and the origin of many of the distinctive coastal features found today, reflects these fluctuations in sea level that alternately exposed and submerged the coastal plain.

About 18,000 years ago, at the end of the last glacial epoch, sea level was about $130 \mathrm{~m}$ lower than today (Fig. 6). This lower sea level caused coastal plain rivers to cut deep valleys across the continental shelf. As the glaciers melted and sea level rose to its current position, these valleys were drowned 


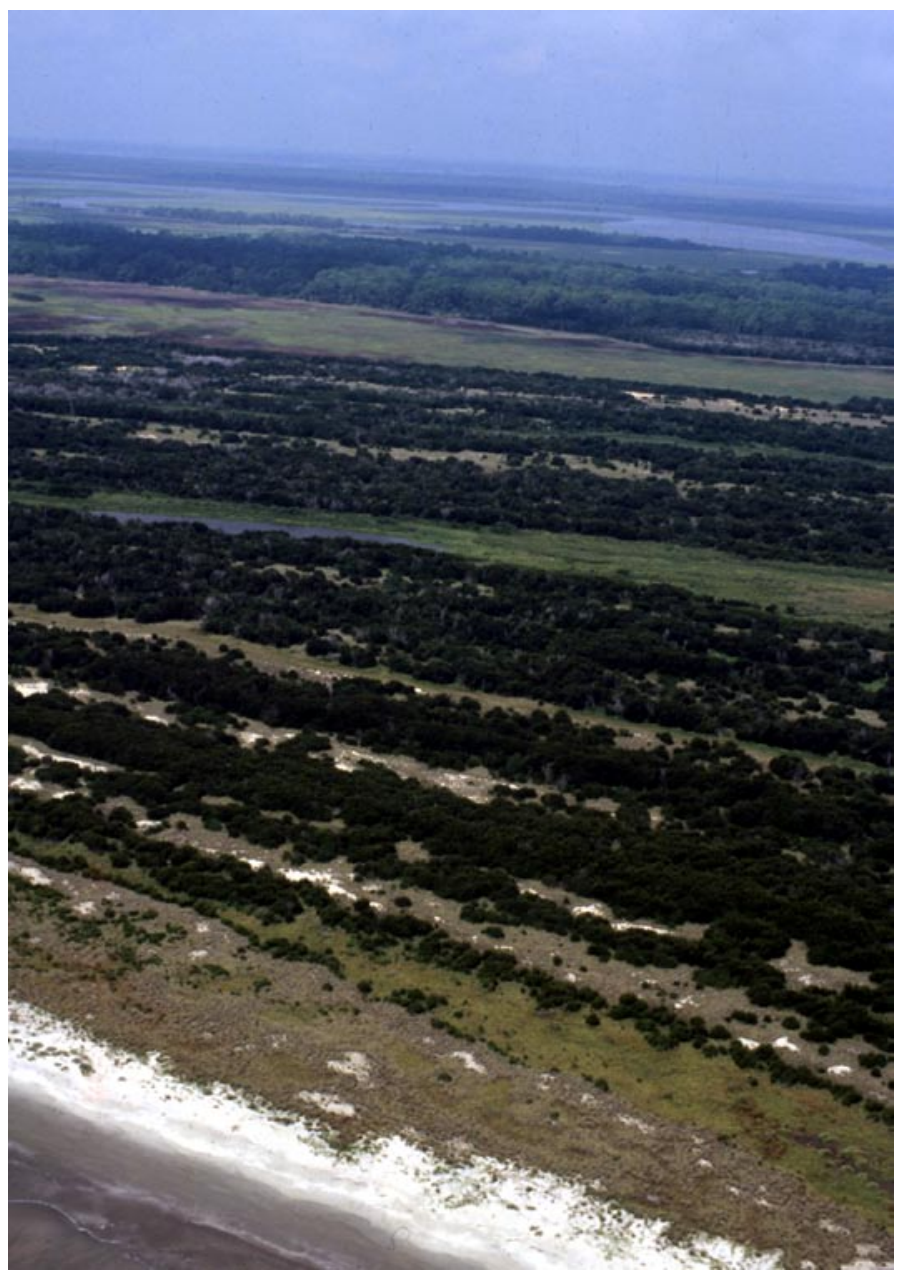

Figure 10. Long linear beach ridges and swales that characterize some Southeast Atlantic barrier islands, such as Little St. Simons Island, Georgia, mark the former positions of the Atlantic shoreline. These features record shoreline accretion at time scales of hundreds to thousands of years.

and most were only partly filled with sediment. The unfilled remnants of former river valleys that rim the Southeast Atlantic coast are the major estuaries, such as Charleston Harbor, and Albemarle Sound.

Post-glacial climatic changes had dramatic effects on the amount of water and sediment transported by the coastal-plain rivers draining into the Atlantic Ocean. As rainfall decreased, so did stream flow and sediment load, which caused some river deltas to retreat. While the deltas were retreating, some adjacent beaches and barrier islands that had been migrating landward began to build seaward as a result of locally abundant sand supply. The sand that built the accreting shores was supplied by erosion of mainland shores and reworking of Pleistocene barrier-island and deltaic sediments on the continental shelf that were submerged by the rising sea. Numerous beach ridges that mark successive former positions of the Atlantic shoreline (Fig. 10) are evidence of the abundant supply of older sand.

Riggs and others (1995) described shoreface settings along the North Carolina coast and explained how semi-indurated and indurated strata underlying the perched beaches and barrier islands influenced the: (1) nearshore physical processes, (2) production of beach sediment from the submerged outcrops, (3) shape of the shoreface, and (4) long-term movement of the shoreline. Similar conclusions regarding geologic framework and shoreline movement were reported for South Carolina by Gayes and others (2003). The shoreface classifications and associated shoreline conditions reported by Riggs and others (1995) could be applied to other segments of the Southeast Atlantic region where sand supply is limited and older strata are either exposed at or are near the sea floor.

\section{Coastal Processes}

The Southeast Atlantic coast is a storm-dominated region that is constantly changing as a result of active coastal processes that are directly linked to meteorological events. Winddriven waves and tidal currents are the most important geological agents controlling sediment transport and evolution of the Southeast Atlantic shores. Wind directions and intensities vary seasonally with southerly winds prevailing most of the year. During the winter months, wind-circulation patterns and low barometric pressures preceding the passage of cold fronts cause strong onshore winds and high waves that typically erode the beach. After each frontal system passes the coast, wind direction shifts and strong northerly winds can generate waves that erode estuarine and backbarrier shores at many locations.

Tidal range of the Southeast Atlantic coast is influenced by the configuration of the shore and continental shelf (Redfield, 1958). The semi-diurnal tidal wave is amplified by the Georgia embayment, known as the Georgia Bight, and the tidal range changes systematically alongshore (Nummedal and others, 1977) such that it is highest (maximum $\approx 3 \mathrm{~m}$ ) within the Georgia Bight, but decreases both to the north and to the south. Tidal range generally is lowest (maximum $<1 \mathrm{~m}$ ) in Florida. Wave heights and associated wave energy also vary along the Southeastern Atlantic coast increasing northward from Florida to North Carolina (Nummedal and others, 1977). The combination of tidal and wave forces also varies; North Carolina has moderately high wave energy and moderate tidal energy, South Carolina has moderate wave energy and moderate tidal energy, Georgia has high tidal energy and moderately low wave energy, and Florida exhibits both moderately low tidal energy and wave energy.

Average wave heights in the Southeast Atlantic Ocean range from 0.8 to $1.5 \mathrm{~m}$ in Georgia and North Carolina, respectively (Nummedal and others, 1977). The largest waves and highest sustained wind speeds accompany major hurricanes. They also are responsible for the most property damage and 
loss of lives. Hurricanes tracking along the Southeast Atlantic coast normally follow a northward or westward path (Fig. 11). The preferred paths of the storms determine the likelihood that a storm will make landfall at a particular site. Using historical sites of hurricane landfall, the National Hurricane Center has shown that the areas at greatest risk are southeastern Florida, South Carolina, and North Carolina (Simpson and Lawrence, 1971). Georgia has the lowest risk because of the position of its embayed shoreline relative to the tracks of most Atlantic hurricanes.

Before crossing the Southeast Atlantic coast, the counterclockwise circulation of hurricane wind drives nearshore currents and large volumes of beach and shoreface sand alongshore. High tides, large waves, and strong currents that accompany the storms can leave semi-permanent marks on the barrier islands and beaches. For example, in 2003, Hurricane

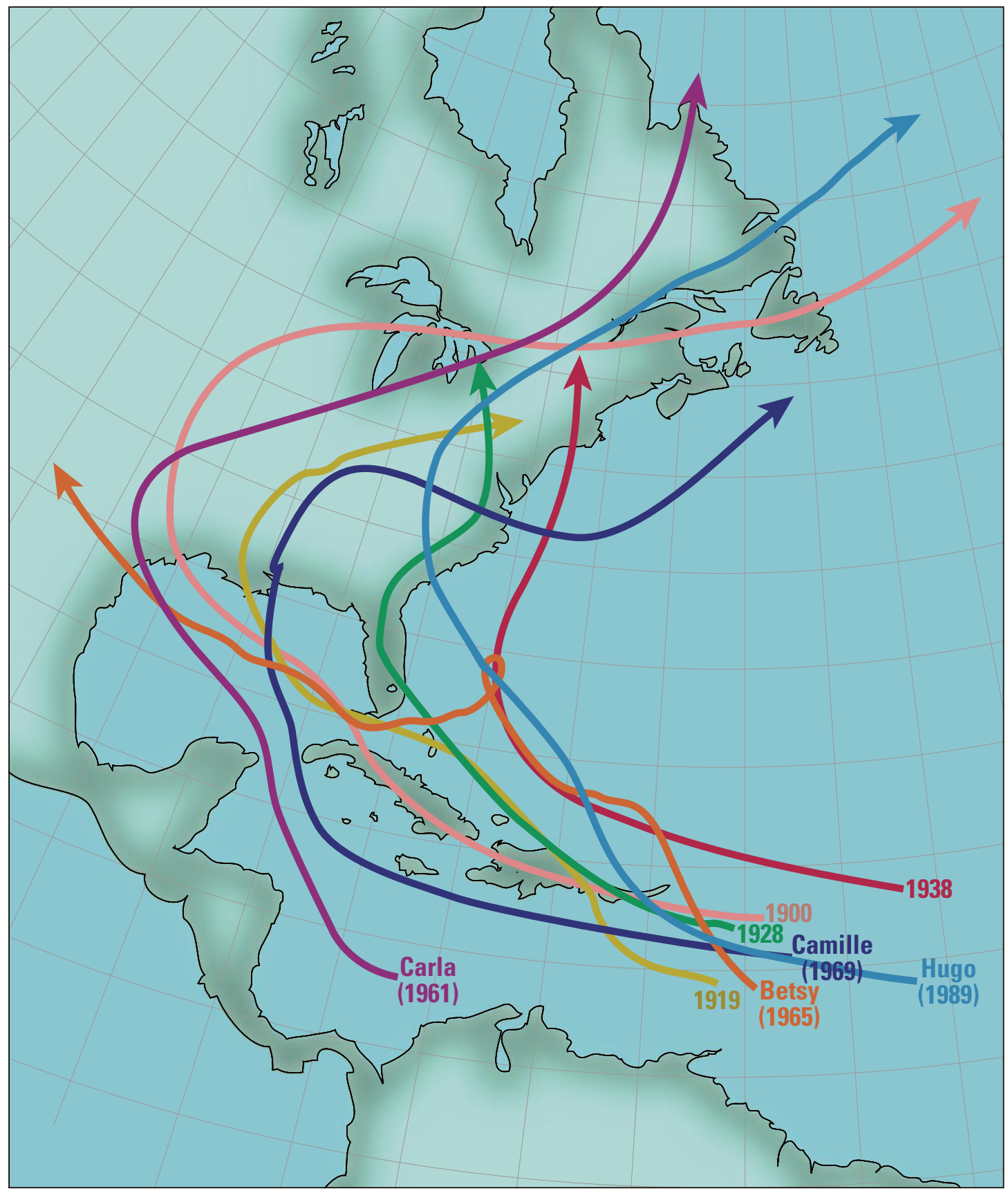

Figure 11. Tracks of some of the most deadly and destructive Atlantic and Gulf hurricanes in the 20th century. Data are from the National Hurricane Center. 


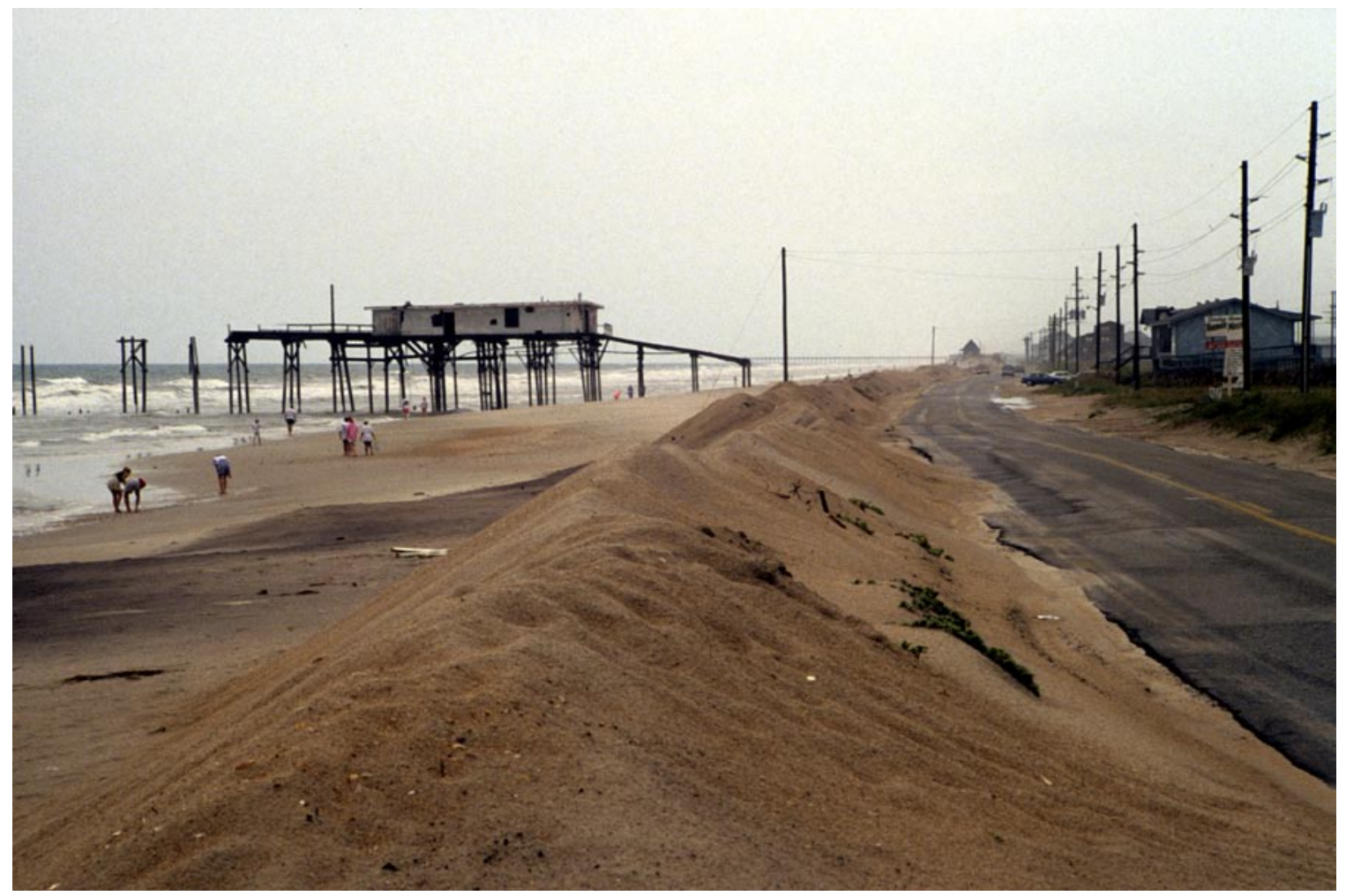

Figure 12. Erosion of the Atlantic shore can destroy roads and eliminate the beach. This example at Topsail Island, North Carolina, shows the effects of long-term erosion and efforts to protect the highway.

Isabel eroded the dunes along Hatteras Island, North Carolina, and cut several channels through the coastal highway. Shortly after the storm, the North Carolina Department of Transportation created an artificial dune ridge by bulldozing sand from the overwash terrace and pumping up sand from offshore to fill in the breaches. A similar but smaller artificial ridge was constructed from beach sand to protect the coastal road from erosion on Topsail Island, North Carolina (Fig. 12). In Florida, even relatively weak storms have destroyed piers, seawalls, dune walkovers, swimming pools, roads, houses, motels, and other buildings because structures were poorly sited and the beach did not recover from storm erosion before the next storm arrived (Clark, 1986). In 2004, two hurricanes only a few weeks apart (Francis and Jeanne) struck the east coast of Florida (Florida Department of Environmental Protection, 2004), causing more erosion and property damage than either storm would have on its own (Fig. 13).

Tide-gauge records along the Southeast Atlantic coast since the turn of the century all show the same general variations in sea level (Fig. 14). Annual variations are controlled by meteorological and oceanographic factors (Hicks, 1968). The tide-record trends show that some areas, such as Key West, are relatively stable because the underlying hard limestone substrates are stable. Other tide records, such as at Charleston, show a slightly higher relative rise in sea level of about 3.3 $\mathrm{mm} / \mathrm{yr}$ during the 20th century (Lyles and others, 1988). This rate of rise is about twice as fast as the global rise in sea level, which recently has averaged about $1.8 \mathrm{~mm} / \mathrm{yr}$ (Gornitz and Lebedeff, 1987).

The difference between recorded rates of submergence along the Southeast Atlantic coast and the global rate of sealevel rise is caused mostly by subsidence. Releveling surveys show that the subsidence is related to regional tilting of the coastal plain; areas near and seaward of the shoreline are sinking while inland areas are being uplifted (Holdahl and Morrison, 1974). Within the regional trend are areas where subsidence rates are relatively high, such as near Savannah, where accelerated sinking is attributed to groundwater withdrawal (Davis, 1987).

\section{Sand Sources}

Eroding beaches and sand shoals on the adjacent inner continental shelf are the primary sources of sand for maintaining the Southeast Atlantic barriers and beaches. Southeast Atlantic rivers generally do not contribute significantly to the present sand budget of the beaches because most of the rivers empty into estuaries and deposit their sediment loads far inland from the Atlantic shoreline. A few moderately large Piedmont-draining rivers, such as the Altamaha and Savannah in 

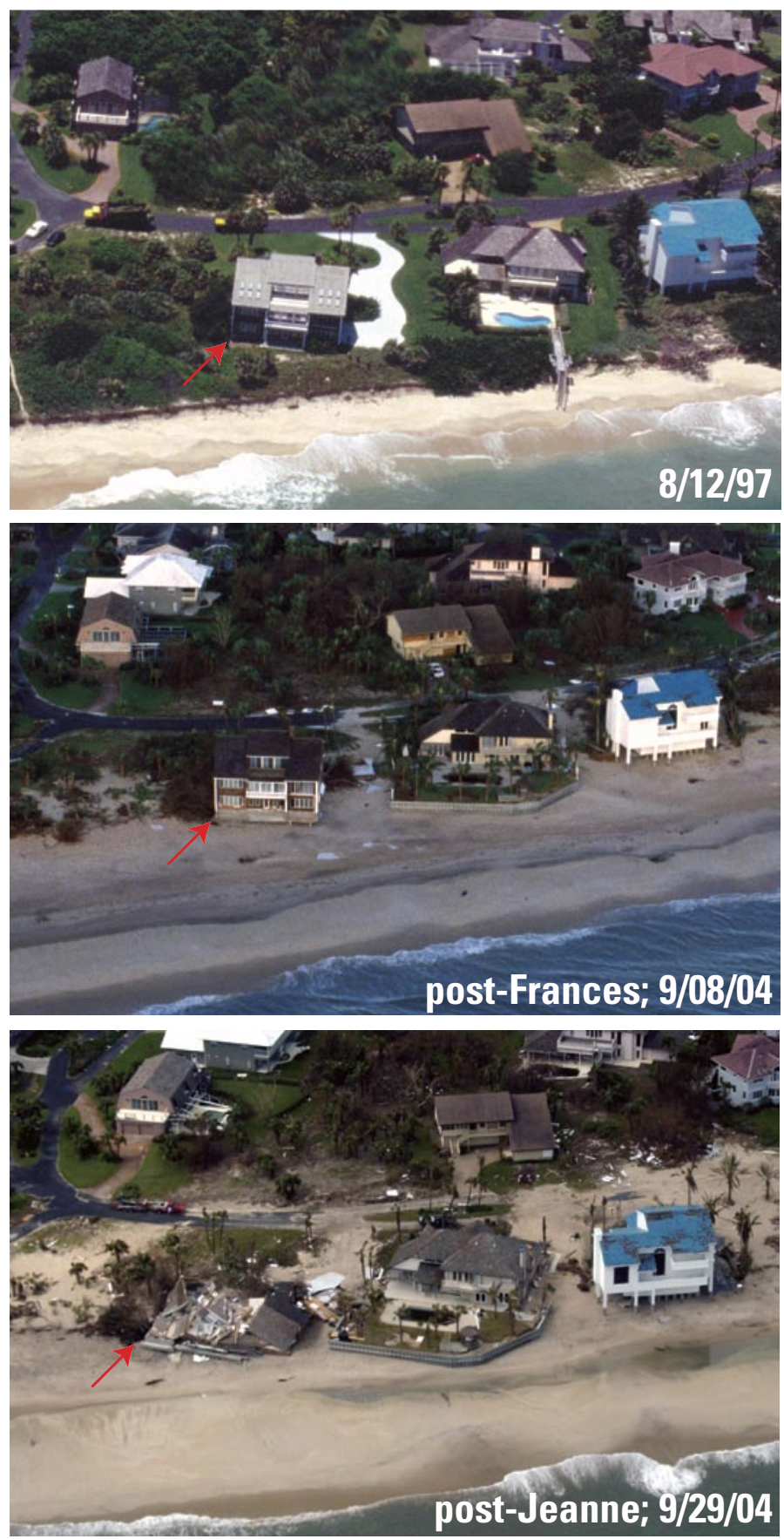

Figure 13. Erosion and property damage near Floralton Beach, Florida caused by Hurricanes Francis and Jeanne in 2004.

Georgia and the Santee-Pee Dee in South Carolina, added sand directly to the littoral system before they were modified by dam construction or river diversion that greatly reduced their sand supply to the coast (Hayes, 1994).

Sand supply was further disrupted by other human activities such as dredging channels and constructing jetties. The jetties and navigation channels at inlets disrupt the longshore currents and compartmentalize the coast, preventing sediment exchange from one coastal segment to another. Before the littoral drift system was altered, sand was naturally transported around tidal inlets and shared between neighboring coastal segments. Now there are many coastal compartments isolated by long impermeable jetties or deep navigation channels like those maintained at the entrance to $\neg$ Charleston Harbor. The history of Morris Island, South Carolina, is a good example of how jetty construction has influenced shoreline movement. Before jetties were constructed in 1896, Morris Island was a beachridge barrier wider than Folly Island, but the jetties blocked the alongshore supply of sand to Morris Island and it began eroding rapidly and pivoting as it migrated landward (Lennon and others, 1996). The lighthouse that once was on land now stands surrounded by water more than $600 \mathrm{~m}$ offshore (Fig. 15).

\section{GENERAL CHARACTERISTICS OF THE SOUTHEAST ATLANTIC SHORES BY STATE}

The east coast of Florida consists largely of long, narrow, sandy barrier islands that are backed by diverse wetlands. Mangroves occupy the backbarrier settings from Miami Beach to Vero Beach, whereas backbarrier salt marshes are present north of Vero Beach. Florida east coast barriers tend to be long and narrow because they are wave dominated and the sand supply is low. An exception is Amelia Island in north Florida, which resembles the wide, tide-dominated barrier islands of Georgia. The Florida barriers are separated by only a few natural tidal inlets, which are widely spaced and small because the tidal range is low and freshwater inflow is minor. Mainland beaches are prominent in Flagler County and Broward County. A feature unusual for the Florida coast is Cape Canaveral, a cuspate foreland that consists of multiple beach ridges separated by narrow, shallow lagoons. Florida rivers flowing to the Atlantic Ocean have small drainage areas and they do not transport the large volumes of sand necessary for building or maintaining beaches or the large volumes of water capable of creating large estuaries. Outcrops of beachrock and other indurated strata, which are common in the nearshore zone south of Cape Canaveral, are evidence of the low sand supply. These hard outcrops can slow the rates of shoreline erosion locally.

Short, wide barrier islands that are backed by extensive salt marshes and separated by large tidal inlets characterize the Georgia coast. Some of the barriers continue to receive sand and are accreting, whereas others are experiencing long-term erosion (Fig. 16). The morphologies of the barriers and inlets, which are similar to those of northern Florida (Amelia Island) and southern South Carolina (Hilton Head), are a result of the relatively high tidal range within the Georgia Bight. Even though the barriers do not adjoin lagoons, they are referred 


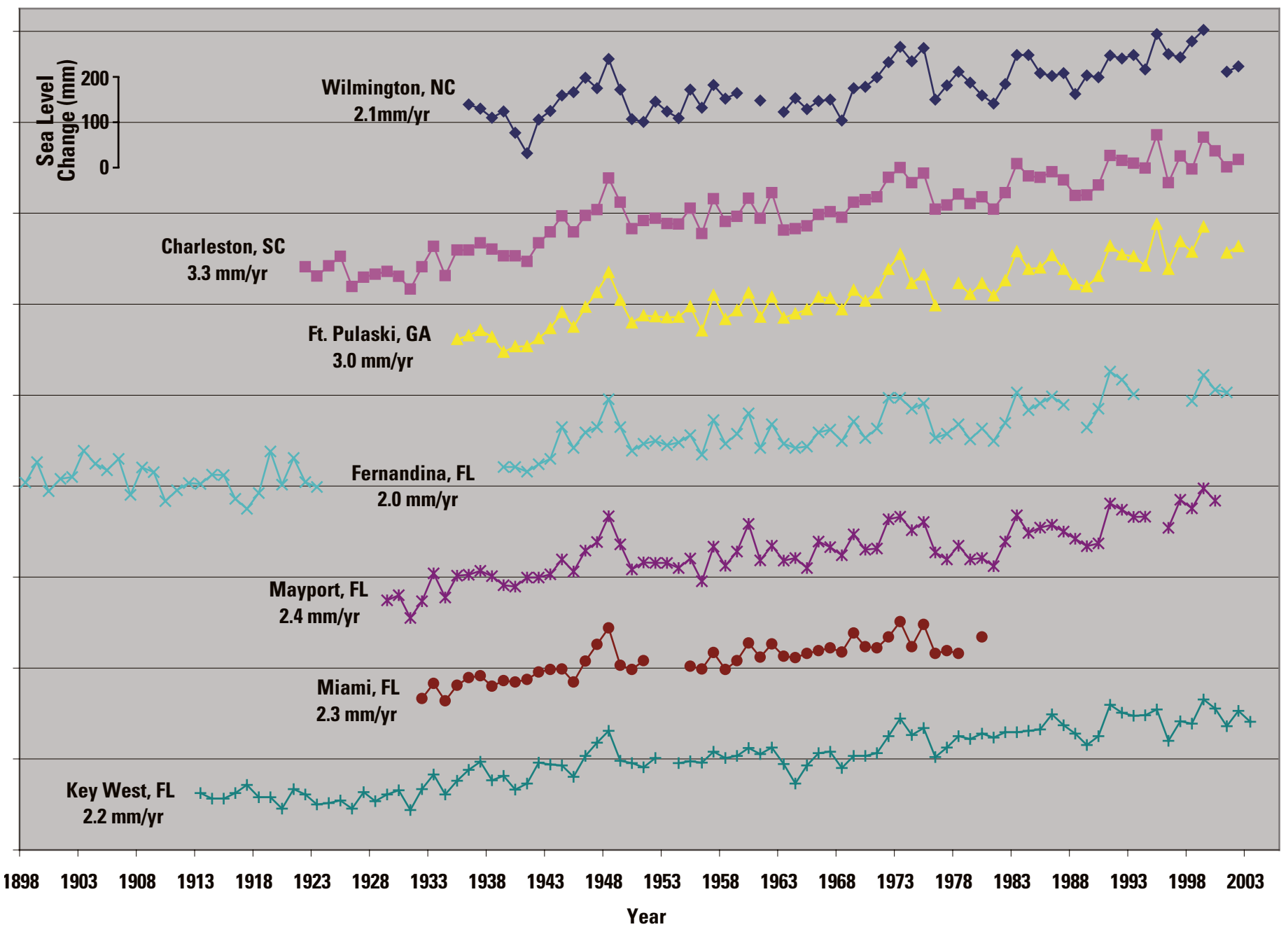

Figure14. Long-term trends in average annual sea level at selected tide gauges in the Southeast Atlantic 0cean. Data are from the National Ocean Service.

to as Sea Islands because they are surrounded by water at high tide when the marshes are flooded (Hayes, 1994). Other prominent features of the Georgia coast are the funnel-shaped river mouths that also are characteristic of coastal areas with a relatively high tidal range. Many of the Georgia barriers are inaccessible except by boat and therefore are largely undeveloped (Clayton and others, 1992).

The South Carolina coast has a variety of landforms that are products of variable sediment supply and coastal processes. The southern half of the coast, which has the highest tidal range, consists of both wide and stable barrier islands and narrow migrating barrier islands. Moderately large tidal inlets separate the islands. In contrast, the northern half of the South Carolina coast consists of narrow barriers and salt-marsh shores of the Cape Romain/Santee delta (Fig. 9), or sandy beaches and dunes of the mainland shore along the Grand Strand. No rivers cross the mainland shore of the Grand Strand, and only a few tidal inlets interrupt its long sandy beaches. Exposures of dead trees on the beaches of some South Carolina barriers, such as Pritchards Island (Fig. 17), are clear evidence of long-term shoreline erosion.

The coast of North Carolina is also morphologically diverse. A mainland shore extends from Little River Inlet, at the border with South Carolina, to Cape Fear. The most prominent features on the North Carolina coast are the sandy capes (Cape Fear, Cape Lookout, and Cape Hatteras) where the shoreline orientation changes dramatically (Fig. 1). Much of the shore between the capes consists of long, narrow barrier islands separated by small tidal inlets. The barriers are progressively more clearly defined and separated farther from the mainland shore between Cape Fear and Cape Lookout. North of Cape Lookout, broad lagoons (sounds) separate the barriers from the mainland. 


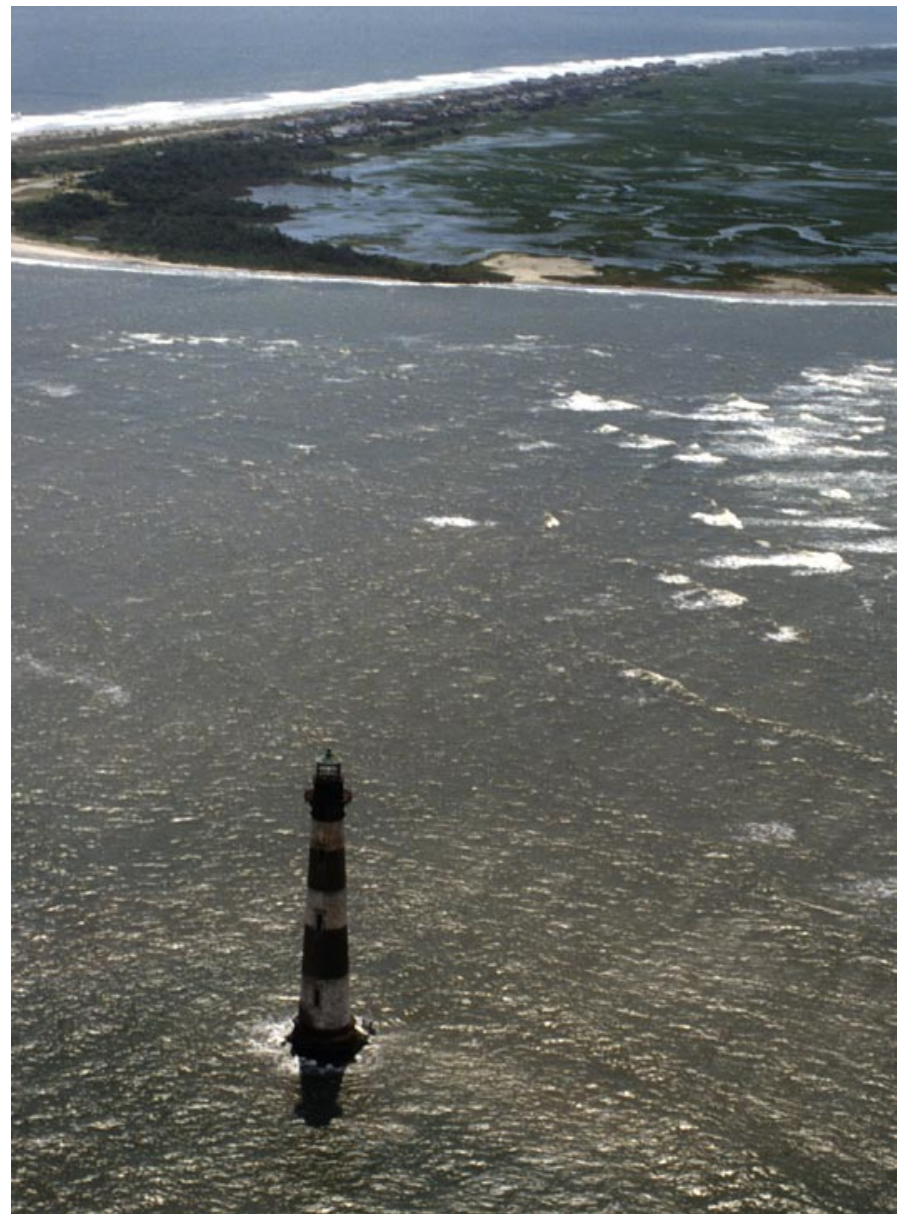

Figure 15. Jetty construction at Charleston Harbor, South Carolina caused chronic beach erosion on adjacent Morris Island that left the lighthouse isolated far offshore in the Atlantic Ocean.

\section{HISTORY OF INFRASTRUCTURE DEVELOPMENT}

Since their early occupation by European settlers, the Southeast Atlantic barriers and mainland shores have served as safe harbors that promoted early economic development related to shipping and other maritime activities. Barrier islands strategically located at the mouths of major estuaries were the sites of quarantine stations, supply docks, military installations, and trading posts.

The oldest city in the U.S., which was established by the Spanish in 1565, is St. Augustine, located on the east coast of Florida at the mouths of the Matanzas and Tolomato Rivers. The most advanced technological site is at Cape Canaveral, which is the launch and landing site for the space shuttle and other NASA space exploration activities. In general, development of the east Florida coast was gradual but increased begin- ning in the mid-1800s. What is now Miami Beach was a narrow strip of sand covered with mangroves before it was cleared and filled for construction beginning in the mid-1800s (Pilkey and others, 1984). High-density development accelerated during the post-World War II building boom, and many of the building practices were not suitable for coastal construction. Hurricanes exposed many of these construction deficiencies shortly after development began, but some of the consequences are still being experienced. For example, beach houses built in the 1950s south of Miami did not present a problem until 1992 when Hurricane Andrew destroyed many of them.

The histories of settlement and eventual recreational development of the beaches and barriers of Georgia, South Carolina, and North Carolina are similar. They all were initially sites of sparse occupation in the 1500s by the Spanish or French, but later fell under the control of the English, who established small colonies. Before the Civil War, some barrier islands in Georgia and the Carolinas were the sites of vast plantations for crops such as cotton, tobacco, and rice. Development after the Civil War for tourism and recreation was slowed by the lack of access. The construction of bridges and roads by military operations in the 1940s facilitated the rapid post-World War II development of some of the barrier islands (Pilkey and others, 1998).

The Southeast Atlantic barriers have always had a strong military presence beginning with early construction of forts. In fact, fortifications and training facilities represent the earliest occupation of some Southeast Atlantic barrier islands. Fort construction began as early as 1672 (St. Augustine, Florida) and continued through the mid-1800s. Later, other military facilities were constructed on barrier islands as training sites used during World War II (Pilkey and others, 1984).

Some of the oldest landmarks, like lighthouses and forts, are especially vulnerable to erosion because these aids to navigation and military defense were strategically located on the tips of barrier islands or on points of land that provided unobstructed visibility. These structures also provide a basis for determining long-term shoreline change. For example, the Cape Hatteras lighthouse, built more than $450 \mathrm{~m}$ landward of the shore in 1870, had to be relocated because of long-term beach erosion (Pilkey and others, 1998). The lighthouse at the entrance to Charleston Harbor also stands as a testament to the vulnerability of coastal structures. This structure was built on Morris Island, but the island migrated westward more than 600 $\mathrm{m}$, leaving the lighthouse exposed to wave attack (Fig. 15). The lighthouse is now surrounded by water and protected by a rock revetment that prevents it from being completely undermined and destroyed (Lennon and others, 1996).

Most developed beaches of the Southeast Atlantic region front private property. The longest publicly owned beaches belong to federal agencies including the National Park Service, which is responsible for managing the Canaveral National Seashore in Florida, Cumberland Island National Seashore in 


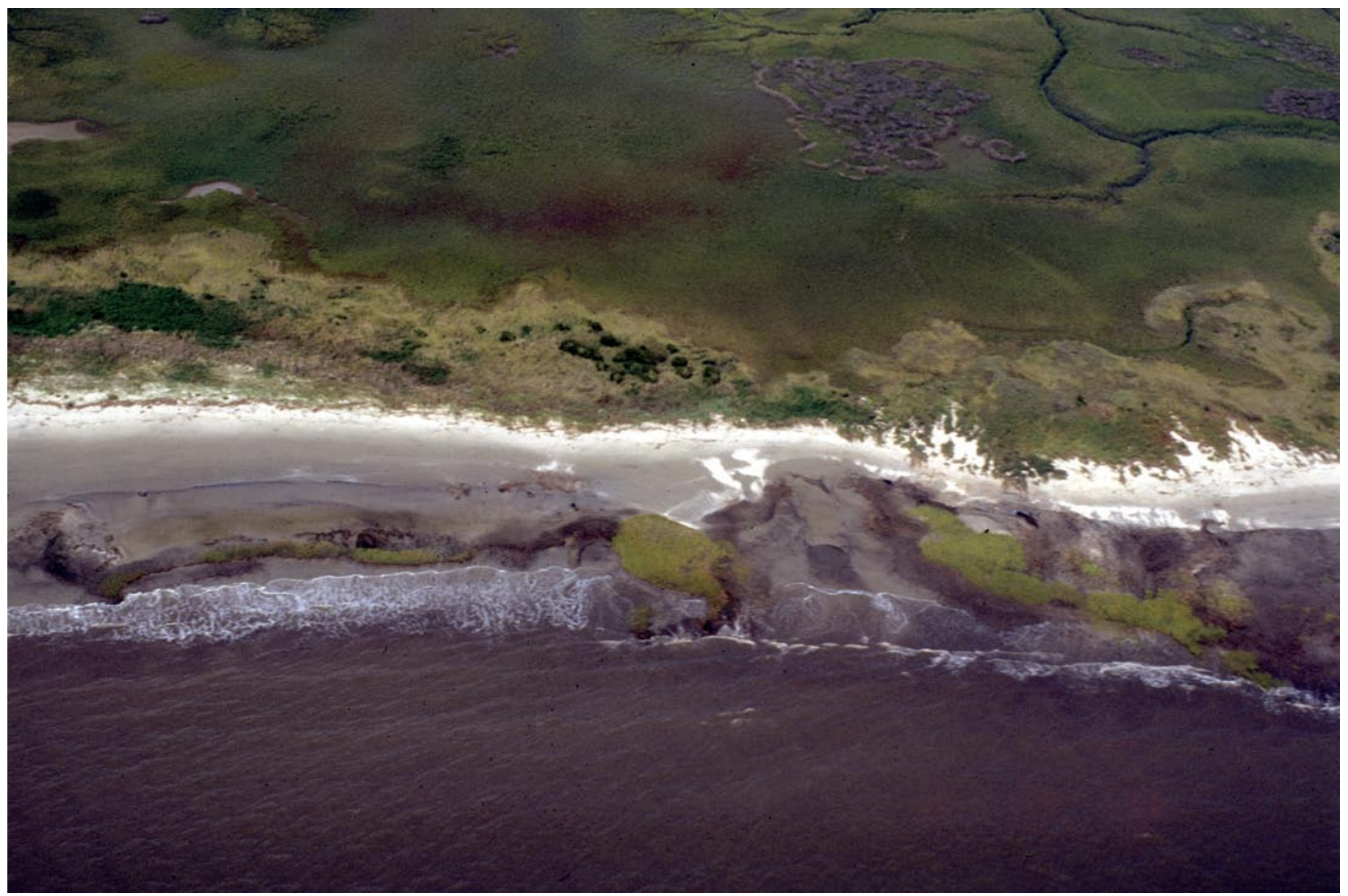

Figure 16. Outcrops of muddy marsh sediments on the lower beach are evidence of long-term erosion. This example is from Wolf Island, Georgia.

Georgia, and the Cape Hatteras and Cape Lookout National Seashores in North Carolina. In addition to these federal holdings, the Southeast Atlantic states have many wildlife refuges and state and local parks that account for a significant percentage of the non-private ocean-front property.

\section{SHORELINE CHANGE AND COASTAL LAND LOSS}

In this section, shoreline changes are presented with an emphasis on shoreline erosion, because it is an important natural coastal hazard along many Southeast Atlantic beaches. Table 7 summarizes both long-term and short-term rates of shoreline change as averages of all the changes, including both erosion and accretion, and as averages of only the erosion values and only the accretion values. Distinguishing between erosion and accretion provides more quantitative detail to the results.
The summary discussion includes references to shoreline erosion and to the broader issue of coastal land loss in order to provide a more complete perspective of coastal change. In the Southeast Atlantic states, coastal land loss is occurring primarily because of episodic high wave energy, natural changes in the coastal system, and as a consequence of human activities. Additional information about coastal land loss is available in a USGS Open-File Report at http://pubs.usgs.gov/of/2003/of03$337 /$.

\section{East Florida}

Land losses on the east coast of Florida are primarily associated with erosion of sandy beaches and barrier islands, especially around inlets (Clark, 1990) where swift tidal currents easily remove the loose sand that forms the ends of the barriers. Land loss along the lagoon shores generally is minor because these water bodies are narrow or are already protected by erosion control structures such as bulkheads. Wakes generated by 


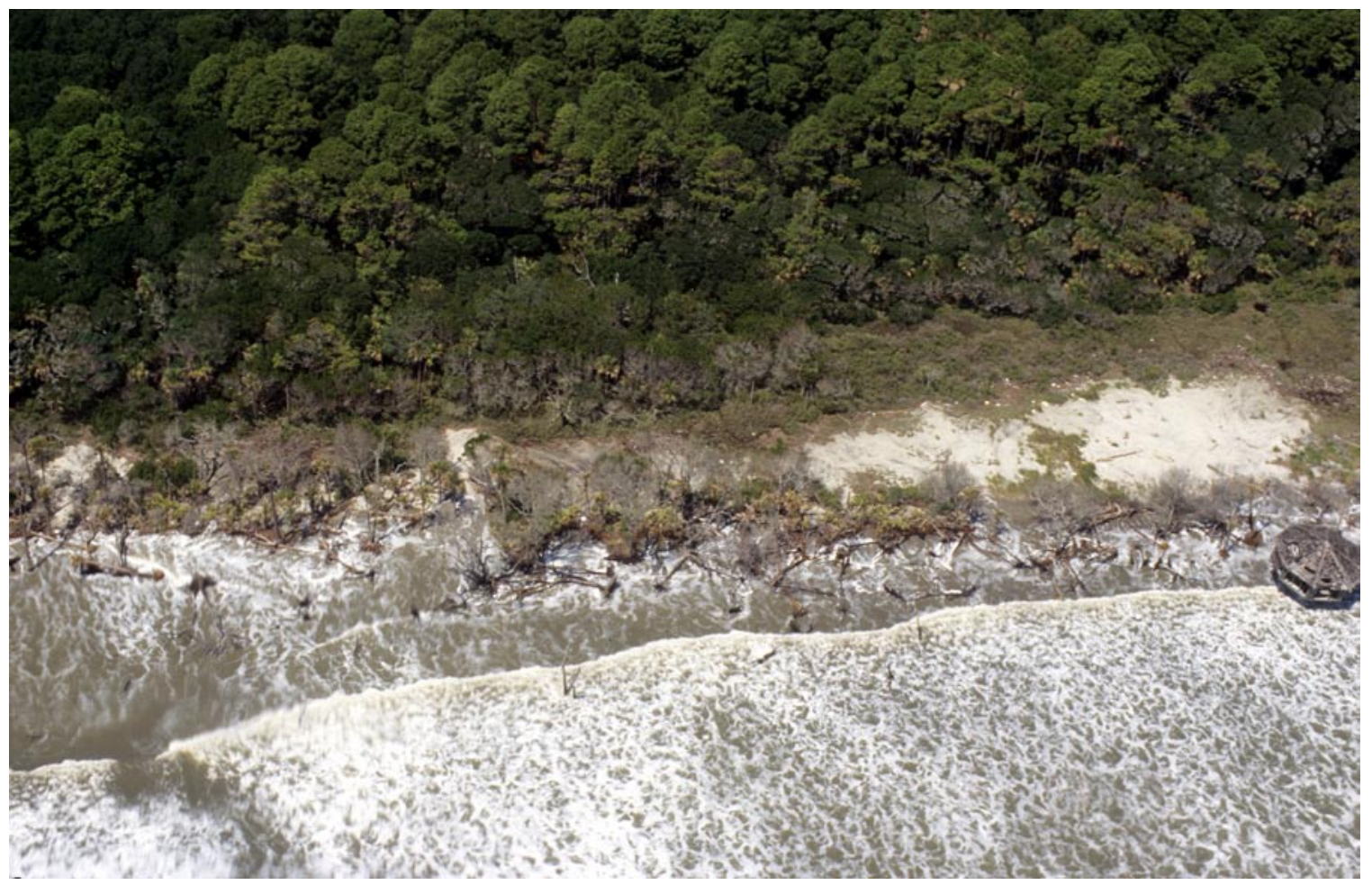

Figure 17. Dead and fallen trees and beach houses in the surf zone are indicators of long-term beach erosion. This example is from Pritchards Island, South Carolina.

boats in the lagoons, such as along the Intracoastal Waterway, can contribute to local bank erosion in some areas.

Compared to historical shoreline changes in the other Southeast Atlantic states, the average long-term change rate of $0.2 \pm 0.6 \mathrm{~m} / \mathrm{yr}$ for east Florida (Table 7a) was low, primarily because tidal and wave energy were low and beach nourishment projects were common where erosion persisted. Even though long-term erosion rates were generally low (average is $-0.5 \mathrm{~m} / \mathrm{yr}$ ), at least $39 \%$ of the Atlantic shoreline experienced long-term erosion. The highest long-term rates of erosion were observed at the southern end of Amelia Island on the margin of Nassau Sound, and relatively high rates of erosion persisted along the northern end of Jupiter Island at Jupiter Inlet. Longterm and short-term trends and rates of shoreline change were similar, such as around Cape Canaveral, where there was apparently little or no alteration of the sediment supply. Slow but chronic erosion along the east coast of Florida eventually results in narrowing of the state's valuable recreational beaches, and many highly developed beaches have no dunes to protect buildings from large storm waves and flooding. Consequently, beach nourishment is commonly used to mitigate the effects of long-term erosion. Short-term shoreline stability or accretion increased where beach nourishment was common, such as along Miami Beach and Jacksonville Beach.

The Florida Department of Environmental Protection Bureau of Beaches and Coastal Systems reports that much of the east coast of Florida is undergoing critical erosion. Their definition of critical erosion is based on the vulnerability of resources to erosion rather than on the rate of erosion; therefore, even low rates of erosion would be critical in most areas of economic development.

\section{Georgia}

In Georgia, coastal land loss is caused primarily by erosion of the Atlantic Ocean beaches. Open lagoons are not present landward of the barrier islands and estuaries are small, so erosion of backbarrier shores and interior marshes is not a significant component of coastal land loss in Georgia as it is in other states. Other mechanisms that cause land loss, such as coastal submergence, appear to be minor in Georgia (Fig. 14).

Analysis of long-term historical shoreline change indicates that $65 \%$ of the Georgia shore was stable or accreting, with an overall average shoreline change rate of $1.0 \pm 2.7 \mathrm{~m} / \mathrm{yr}$ (Table $7 \mathrm{a})$. The eroding portion of coast had an average erosion rate of $-1.5 \mathrm{~m} / \mathrm{yr}$. Highest long-term erosion rates $(-9.4 \pm 4.0 \mathrm{~m} / \mathrm{yr})$ occurred along Wolf Island (Fig. 16). The spatial patterns of historical shoreline changes in Georgia were highly variable, with eroding and accreting segments located adjacent to one another. Despite the high lateral variability, both long-term and short-term shoreline changes were similar for the same 
beach segments. Short-term rates of change were higher than long-term rates, and erosion increased slightly from $35 \%$ for the long-term period to $40 \%$ for the short-term period. Erosion persisted along segments of Tybee, St. Catherines, Wolf, north St. Simons, north Jekyll, and central Cumberland Islands. Many beach segments reported by Griffin and Henry (1984) to be experiencing long-term erosion continued to erode, except for the areas influenced by beach nourishment.

\section{South Carolina}

Some of the highest rates of shoreline retreat and land loss in the Southeast Atlantic region are found in coastal South Carolina. Land losses are concentrated primarily along eroding beaches of the Atlantic Ocean; however, some land loss occurs around backbarrier marshes, along tidal creeks and mud flats, and other shores of the estuaries, but rates of erosion have not been determined (Lennon and others, 1996).

The alongshore patterns of shoreline changes along the Atlantic Ocean in South Carolina were highly variable, and eroding and accreting beach segments were located close to one another. On some barriers, such as Edisto and Hunting Islands, beach erosion was severe on the northeastern end, whereas beaches were stable or accreting on the southwestern end. This spatial pattern indicates alongshore transfer of sand by southwesterly-directed ocean currents. Despite the high lateral variability, both long-term and short-term shoreline changes were similar for the same beach segments. The overall long-term trend of shoreline change was erosion for $51 \%$ of the shore, with a long-term average erosion rate of $-0.5 \pm$ $3.0 \mathrm{~m} / \mathrm{yr}$. The highest long-term rate of erosion $(-13.0 \pm 18.8$ $\mathrm{m} / \mathrm{yr}$ ) was at the northeastern end of Hunting Island. Longterm erosion persisted on segments of Fripp, Hunting, Edisto, Morris, Bull, and Cape Islands. For the short-term period, the percent of eroding shoreline decreased to $39 \%$, probably due to beach-nourishment projects, such as along Hilton Head Island, Hunting Island, and the Grand Strand. Although the percent of eroding shoreline decreased in the short-term, the average short-term rate of change increased slightly to $-0.6 \mathrm{~m} / \mathrm{yr}$. This indicates that the average rates of erosion increased enough along eroding segments ( -2.8 in the long-term to $-4.1 \mathrm{~m} / \mathrm{yr}$ in the short-term) to offset the rates of change along stable or accreting segments.

\section{North Carolina}

The longest continuous segments of beach erosion and land loss in the Southeast Atlantic region occurred in North Carolina. This includes land losses associated with erosion of the Atlantic Ocean beaches as well as erosion along estuarine shorelines including coastal marshes and fringe habitats. The high coastal land losses in North Carolina are caused by high wave energy associated with frequent storms and the relative rise in sea level (Riggs and Ames, 2003). The long wave fetches associated with the broad estuaries also contribute to land losses around their margins.

The average long-term rate of change for the North Carolina Atlantic shoreline was erosion at $-0.7 \pm 1.3 \mathrm{~m} / \mathrm{yr}$ (Table $7 \mathrm{a}$ ). About $70 \%$ of the shoreline experienced long-term erosion at average rates of $-1.4 \mathrm{~m} / \mathrm{yr}$. Maximum rates of erosion occurred on the margins of Ocracoke and Hatteras Inlets. Long-term erosion persisted on Smith, Masonboro, Topsail, Ocracoke, south Hatteras, and central Hatteras Islands. The short-term trends show a decrease in the length of eroding coast to about $60 \%$, but for the retreating segments, average rates of erosion increased to $-1.8 \mathrm{~m} / \mathrm{yr}$ (Table 7). The short-term decrease in length of eroding coast was likely a result of extensive beach nourishment projects.

\section{HUMAN RESPONSES TO COASTAL EROSION AND LAND LOSS}

Each Southeast Atlantic state uses a different combination of technical and regulatory responses to combat beach erosion and to mitigate land loss. The technical responses include hard structures, beach nourishment, sand bypassing at inlets, and retreat (Table 8). Many developed interior shores exhibit a patchwork of relatively low-cost structures such as wooden and metal bulkheads, concrete seawalls, revetments, and small groins. Common interior shoreline structures are rubble revetments composed of various materials including large rocks, broken masses of concrete, and wooden bulkheads. These low-cost structures typically become ineffective in less than 20 years because the structures deteriorate and are unable to withstand the repeated forces of storm waves.

Bulkheads, seawalls, and revetments are used to protect portions of some of the Southeast Atlantic open-ocean shores. Pilkey and others (1998) estimated that only $6 \%$ of the North Carolina shore was armored, whereas $27 \%$ of the South Carolina coast and $45 \%$ of the east coast of Florida had been armored. Engineering structures have little effect on beach stability where sand supply is plentiful, but on eroding beaches they can accelerate beach loss by reducing beach width and preventing the growth of dunes.

The following statements illustrate the types of community responses to shoreline erosion in the Southeast Atlantic region. They provide typical examples rather than a comprehensive review of shoreline protection projects within each state. The examples also reveal some of the unintended consequences of shoreline development and subsequent modification.

Hard structures such as seawalls, rock revetments, bulkheads, and groins are common along the east coast of Florida (Fig. 18) where high-density development began more than 80 years ago. Coastal projects that disrupted the alongshore supply 
Table 8. Technical responses to erosion and land loss in the Southeast Atlantic region.

\section{Protect Shore from Wave and Current Energy}

\section{Structural \\ Seawalls \\ Bulkheads \\ Breakwaters \\ Revetments}

\section{Maintain or Increase Sediment Supply}

Structural
Groins
River Diversion
Perched Beaches

Non-structural
Beach Replenishment
Sand Bypassing
Beach Scraping
Dune Restoration
Submerged Berms
Artificial Seaweed

\section{Nullify Sea-Level Rise}

\section{Structural \\ Seawalls \\ Dikes and Levees}

\author{
Non-structural \\ Grass Planting \\ Horizontal Relocation
}

of sediment began in the late 1800s, and structural responses to beach erosion began as early as the 1920s (Pilkey and others, 1984). Many of the structures were destroyed by storms or failed over time and were subsequently rebuilt, only to be destroyed again. The artificial inlet at St. Lucie is an example of unexpected environmental costs resulting from construction of a hard structure (Pilkey and others, 1984). The inlet was opened in 1892, but it shoaled frequently so a jetty was constructed in 1930 to prevent sand from entering the channel. The jetty contributed to beach erosion, so seawalls, revetments, and groins subsequently were constructed to mitigate the erosion. These structures did not prevent erosion and as a result, several beach nourishment projects were undetaken to restore the beach on Jupiter Island (Valverde and others, 1999).

In Georgia, seawalls and rock revetments armor more than half of the shore of the developed barrier islands (Tybee, Sea, St. Simon, and Jekyll) (Clayton and others, 1992). The beach in some areas is wide enough that these structures are not directly interfering with beach processes. Along some portions of Tybee Island, the beach continues to erode despite several attempts to stabilize it with groins, a seawall, and large blocks of riprap.

South Carolina prohibits construction of new engineering structures, such as seawalls and revetments, but some beaches such as on Hilton Head Island, Folly Beach, and Myrtle Beach had already been armored extensively before the no-structure

legislation was passed. North Carolina also has a strict policy prohibiting the placement of hard structures on beaches, and little of the shoreline is permanently stabilized. However, North Carolina has permitted the use of sand bags in the backbeach for emergency protection. Unfortunately, extensive use of sand bags has had the same negative effect on the beaches as hard structures (Pilkey and others, 1998)

Beach nourishment (Fig. 19) is a popular alternative to structural erosion control along the Southeast Atlantic coast. Pilkey and Clayton (1990) and Valverde and others (1999) compiled beach-nourishment data that included the Southeast Atlantic region through 1996. They reported that Florida spent the most money in the region to nourish beaches and had the greatest number of projects, whereas Georgia had the fewest nourished beaches. In Florida, nourishment has been used to counteract long-term erosion of many beaches. Those receiving nourishment multiple times include Fernandina Beach, Amelia Island, Jacksonville Beach, Miami Beach, Jupiter Island, Lake Worth Inlet, Palm Beach, and Delray Beach. Only Tybee Island and Sea Island have been nourished repeatedly in Georgia. Beaches receiving the most nourishment in South Carolina are Hilton Head Island, Hunting Island, Folly Beach, Pawleys Island, and Myrtle Beach. Sand has been trucked and hydraulically emplaced to nourish beaches and to reconstruct dunes multiple times at several sites in North Carolina including Holden Beach, Wrightsville Beach, and Carolina Beach. All of these projects typically have provided only temporary relief from the long-term erosion.

One of the most successful beach-nourishment projects on the Southeast Atlantic coast has been at Miami Beach (Wiegel, 1992). The beach fill has lasted an average of 15 to 20 years because wave energy is low, the rate of relative sea-level rise is low (Fig. 14), and no major storms have impacted the area recently. Even though beach nourishment is a favored method of controlling beach erosion, it can lead to some unfavorable results, such as steep scarps and shelly or rocky beach material. A specific example of undesirable consequences of beach nourishment is the $\neg$ Miami Beach project that derived its fill from offshore dredging near reefs. The beach-fill material contained a substantial amount of rocks (pieces of coral up to $30 \mathrm{~cm}$ in diameter) that were concentrated in the surf zone and on the surface of the beach by wave reworking. The rocks in the surf zone posed a hazard for recreation and had to be removed at substantial additional expense (Wiegel, 1992).

Sand bypassing is another engineering response to beach erosion at inlets where jetties have been constructed to help maintain the inlet for boat traffic. At Lake Worth Inlet, Florida, a small fixed bypassing plant was constructed to transfer sand from the updrift side to the downdrift side of the inlet. Although this bypassing operation may reduce erosion near the inlet, it is unable to transfer the sand as efficiently as the natural unimpeded waves and currents. Therefore, sand bypassing may 


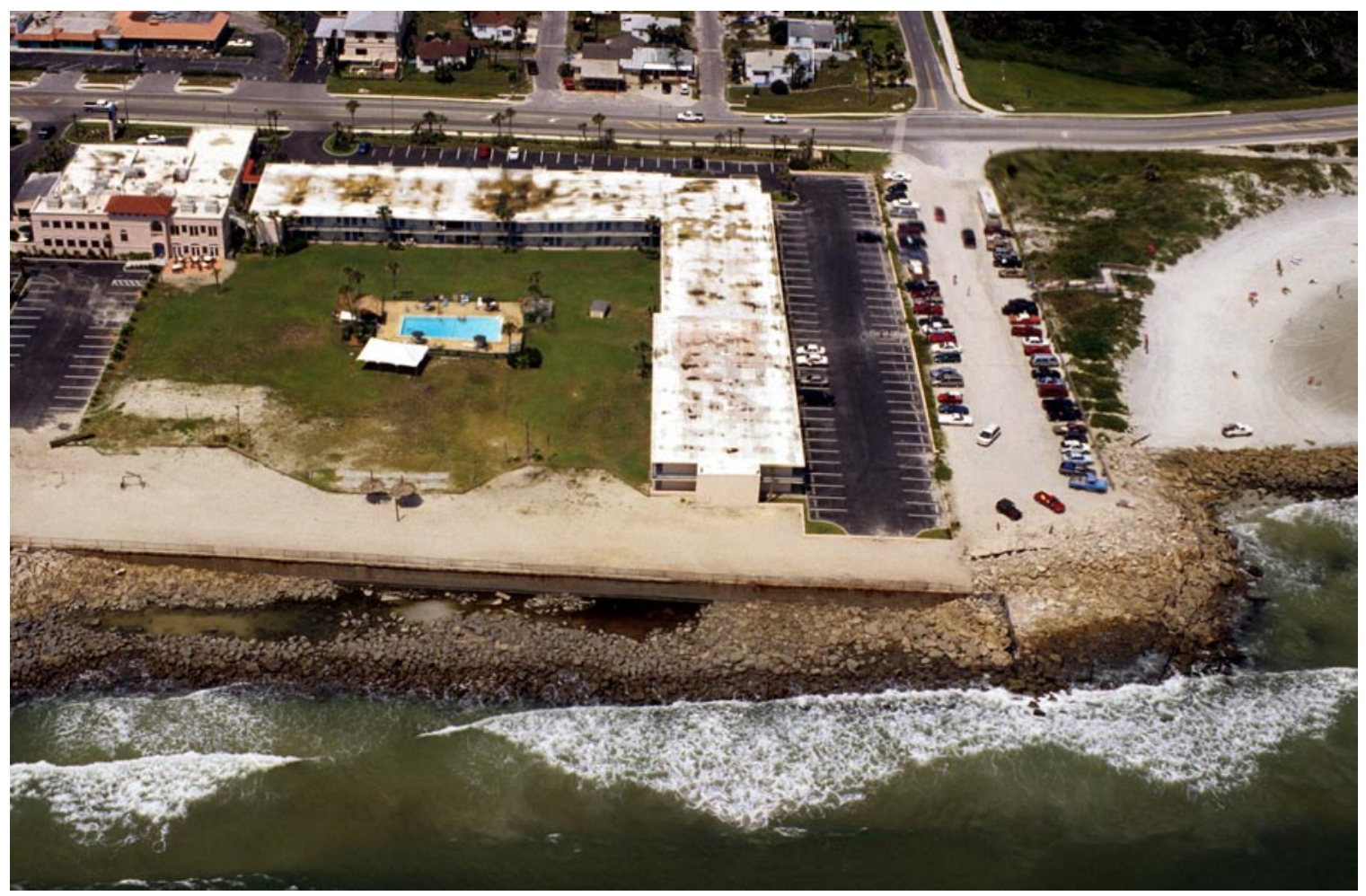

Figure 18. Multiple structures including a seawall and riprap revetment on Anatasia Island, Florida, protect the upland property from wave attack but do not prevent erosion and loss of the beach.

not entirely compensate for the erosion caused by the channel dredging and jetty construction.

Submerged berms (Table 8) are another non-structural response to beach erosion near tidal inlets. They are constructed of sediment dredged from navigation channels and are promoted as a solution to two problems, disposal of dredged material and mitigation of beach erosion. The dredged material is deposited under water in a low mound parallel to the beach and in relatively shallow water. The berm acts as a submerged breakwater, causing large waves to break offshore, thus reducing storm beach erosion. If the berm is oriented properly and built in shallow water, the waves may transfer some of the sand onshore and add to the forebeach. Along the Southeast Atlantic coast, the Army Corps of Engineers has constructed a submerged berm to reduce erosion and storm damage at New River Inlet, North Carolina (Schwartz and Musialowski, 1977). Submerged berms are not as efficient in controlling erosion as beach nourishment, but they are also less costly than direct placement of the dredged material on the beach.

Relocation of buildings (Fig. 20) is not a common response to beach erosion and attendant coastal land loss in the Southeast Atlantic region. Nevertheless, there are several examples of relocation, including the famous Cape Hatteras lighthouse, which was moved inland more than $800 \mathrm{~km}$ in 1999. In some Southeast Atlantic states, involuntary retreat from the eroding shoreline has been the result of both physical and legal forces. The resulting landward relocation of houses and highways is designed to maintain a coastal presence while recognizing the inevitability of future coastal erosion.

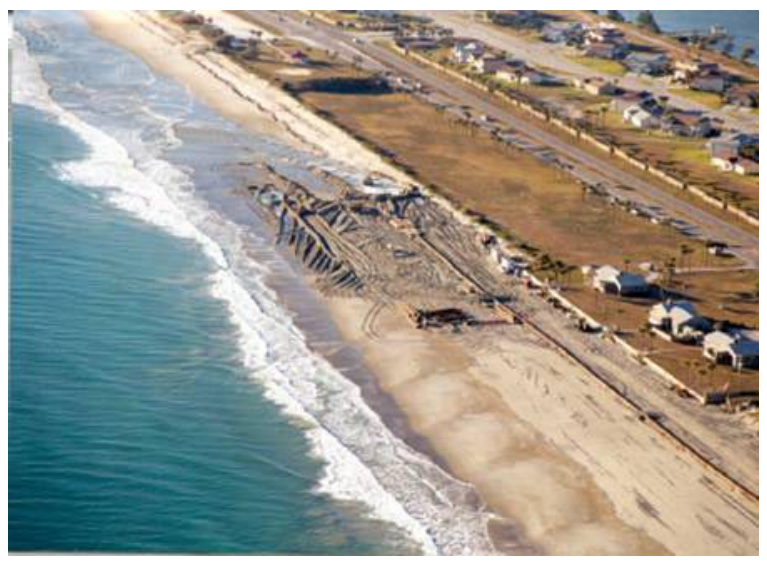

Figure 19. Many beaches along the east coast of Florida, such as this one at Patrick Air Force Base, have been nourished to mitigate against long-term erosion. Photo provided by the Minerals Management Service. 


\section{DISCUSSION AND FURTHER CONSIDERATIONS}

\section{Summary of Shoreline Changes}

According to measurements by the National Ocean Service, states bordering the Southeast Atlantic region have $1870 \mathrm{~km}$ of open-ocean coastline (Shalowitz, 1964). In this report, rates of shoreline change are provided for $1543 \mathrm{~km}$ of shore, which represent the extent of the lidar-derived shoreline. Shoreline-change analyses were not conducted for approximately $17 \%$ of the Southeast Atlantic shore where a lidarderived shoreline was unavailable, such as Bulls Bay, South Carolina, or where all four shorelines were not present (Fig. 3).

Of the Southeast Atlantic shoreline where rates of change were quantified, at least $700 \mathrm{~km}(45 \%)$ eroded with average long-term erosion rates as high as $-13.0 \pm 8.8 \mathrm{~m} / \mathrm{yr}$. Short-term rates of change were slightly lower with about $609 \mathrm{~km} \mathrm{(39 \% )}$ of the evaluated shore eroding in spite of beach nourishment and other attempts to stabilize the shore.

Rates of erosion for the Southeast Atlantic region were generally highest in South Carolina along the northeastern end of barrier islands and also along headland shores associated with the Santee delta. Erosion was also rapid along some barrier islands and headlands in North Carolina. Much of the Georgia Atlantic shore is undeveloped and some natural-beach segments experienced long-term erosion, whereas others experienced long-term accretion. Rates of shoreline change were relatively low along the east coast of Florida where low wave energy and frequent beach nourishment minimized erosion. The highest rates of beach erosion in Florida were generally localized around tidal inlets. Some beach segments in Florida accreted as a result of net longshore drift convergence (Cape Canaveral), and around tidal inlets that were stabilized by jetties.

Comparing long-term and short-term summary values for each state (Table 7a and 7b) shows a systematic decrease in the length (percent) of eroding shore except in Georgia. The decrease in eroding shore and complementary increase in accreting shore may partly be related to the systematic seaward offset in the lidar shoreline and partly to the frequency of beach nourishment. Beach nourishment was common in all the states except Georgia.

The trends and rates of shoreline change presented in this report represent past beach conditions that may not apply to

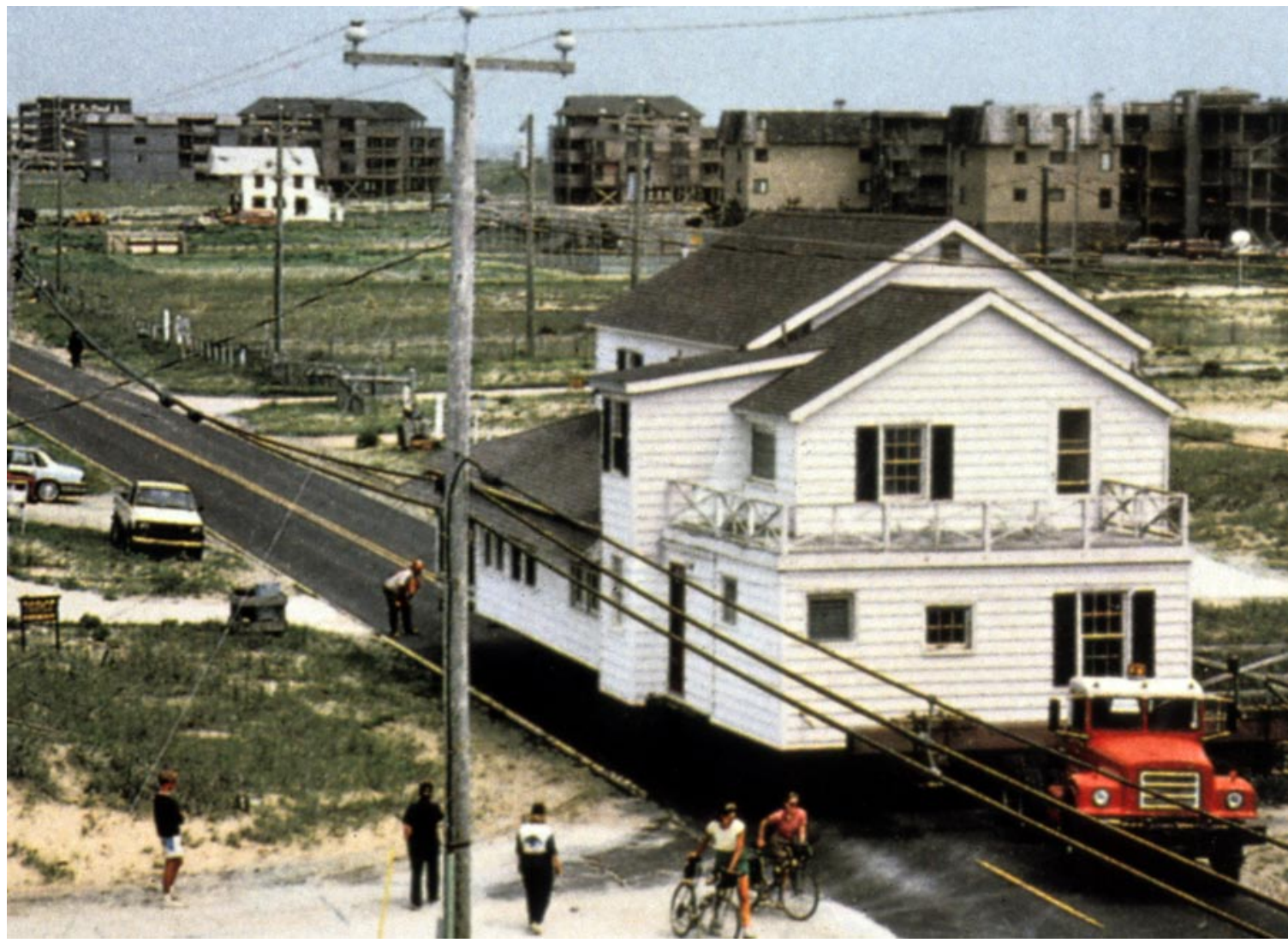

Figure 20. Lateral relocation of a beach house in North Carolina is an example of retreat from the eroding shore. Photo source is unknown. 
present conditions. Major storms that occur after the date of the most recent (lidar) shoreline initiate cycles of beach recession and recovery. Those erosional events commonly alter shoreline positions and rates of shoreline change. An example would be the erosional effects of Hurricanes Francis and Jeanne in 2004 that impacted the same area of the east coast of Florida within weeks of one another. How those back-to-back events will affect long-term shoreline position and rates of change is uncertain.

\section{Planned Updates and Related Research}

The USGS plans to revise and report on rates of shoreline change for the Southeast Atlantic region every 5 to 10 years. The revision interval will depend on the need for updated information and technological advances that will allow relatively rapid shoreline position acquisition, processing, and dissemination. Future revisions will also incorporate the results of ongoing shoreline research. For example, we plan to evaluate the advantages and disadvantages of using the MHWL to determine if another datum-based shoreline would be more suitable for historical analysis. We will also explore other approaches to reduce shoreline-positioning uncertainty (spatial errors) and shoreline-sampling uncertainty (temporal variability). GPS technology has so greatly reduced positioning errors that they are no longer a significant component of the uncertainty analysis like they were in the past. GPS and lidar also eliminate the need for digitization and introduction of their associated positioning errors. Switching from the HWL to the operational MHWL will reduce some of the apparent short-term sampling variability that limits the reliability of the results. A datum-based shoreline that is higher on the beach profile than the operational MHWL might further reduce some of the short-term sampling variability by taking advantage of the more stable portion of the beach profile. The dynamics of sandy beaches ensure that short-term shoreline fluctuations will not be eliminated entirely from future shoreline positions, but data being collected in various coastal regions as part of the USGS regional studies will provide quantitative assessments of seasonal and interannual changes in shoreline position. These assessments will provide a means to determine if the observed shoreline change is within the expected range of movement and allow us to constrain the shoreline position uncertainties further.

Another ongoing topic of research involves non-linear analysis of shoreline movement. It has been shown that timeaveraged linear methods of estimating future rates of shoreline movement (the existing paradigm) may not be appropriate for future predictions of shoreline position because coastal dynamics are non-linear. However, time series analyses based on non-linear theories require numerous shoreline positions (high sampling frequency) that generally are unavailable for most coastal areas.

\section{Influence of Human Activities}

As coastal communities expand along the shores of the Southeast Atlantic region, potential conflicts may arise between preservation of privately owned upland property and conservation of the publicly owned beach. Past responses indicate that these conflicts most likely will be resolved through a combination of beach-nourishment projects and shoreline-protection structures. Both of these engineering responses to erosion alter the natural beach processes and eventually lead to shoreline positions that are not related to the natural unaltered rates of beach erosion.

Adding sand to eroding beaches is the most common method used to mitigate storm damage and to maintain a recreational beach. Beach nourishment alters the rates of retreat by causing rapid artificial accretion of the shoreline. In those areas where nourishment is frequent, the trends of shoreline change will be biased toward accretion or stability, even though the beach is still eroding. Because many beaches are already altered by shoreline-protection projects and many more will be altered in the future, the methods of analyzing shoreline movement will need to take shoreline stabilization activities into account so that the documented trends and derived rates of change can be expressed in their proper context.

Distinguishing between natural rates of shoreline movement and those influenced directly by human activities is crucial when historical rates of change are used for planning and to project future shoreline positions. Improved methods of analyzing shoreline movement will be needed to document the natural rates of shoreline change. 


\section{REFERENCES}

Anders, F. J., Reed, D. W., and Meisburger, E. P., 1990, Shoreline movements Report 2, Tybee Island, Georgia to Cape Fear, North Carolina, 1851-1983: U.S. Army Corps of Engineers, Coastal Engineering Research Center, Technical Report CERC 83-1, $147 \mathrm{pp}$.

Anders, F. J., and Byrnes, M. R., 1991, Accuracy of shoreline change rates as determined from maps and aerial photographs: Shore and Beach, v. 59, p. 17-26.

Barton, C. C., Dismukes, J. S., and Morton, R. A., 2003, Complexity analysis of the change in shoreline position at Duck, NC: Proceedings Coastal Sediments ‘03, $7 \mathrm{p}$.

Blackwelder, B. W., MacIntyre, I. G., and Pilkey, O. H., 1982, Geology of continental shelf, Onslow Bay, North Carolina, as revealed by submarine outcrops: American Association of Petroleum Geologists Bulletin, v. 66, p. 44-56.

Brown, P. J., 1977, Variation in south Carolina coastal morphology, in Nummedal, D., ed., Beaches and barriers of the central South Carolina coast: Field Trip Guidebook for Coastal Sediments '77 meeting, Charleston S.C., p. 11-24.

Chappell, J., Omura, A., Esat, T., McCulloch, M., Padolfi, J., Ota, Y., and Pillans, B., 1996, Reconciliation of late Quaternary sea levels derived from coral terraces at Huon Peninsula with deep sea oxygen isotope records: Earth and Planetary Science Letters, v. 141, p. 227-236.

Clark, R., 1986, The impact of Hurricane Elena and tropical storm Juan on coastal construction in Florida: Florida Department of Natural Resources, Division of Beaches and Shores, Report 85-3, 140p.

Clark, R., 1990, Coastal land loss in Florida: Transactions Gulf Coast Association of Geological Societies, v. 40, p. 117.

Clark, R., 1992, Beach conditions in Florida: Florida Department of Natural Resources, Division of Beaches and Shores, Technical Memorandum 89-1, 200p.

Clayton, T. D., Taylor, L. A. Jr., Cleary, W. J., Hosier, P. E., Graber, P. H. F., Neal, W. J., and Pilkey, O. H. Sr., 1992, Living with the Georgia shore: Duke University Press, Durham, N.C., $188 \mathrm{p}$.

Cleary, W. J., and Hosier, P. E., 1979, Geomorphology, washover history, and inlet zonation; Cape Lookout, North Carolina to Bird Island, North Carolina, in Leatherman, S. P., ed., Barrier Islands from the Gulf of St. Lawrence to the Gulf of Mexico: Academic Press, New York, 237-271.

Crowell, M., and Leatherman, S. P., eds., 1999, Coastal erosion mapping and management: Journal of Coastal Research, Special Issue 28, 196p.

Crowell, M., Douglas, B. C., and Leatherman, S. P., 1997, On forecasting future U.S. shoreline positions: A test of algorithms: Journal of Coastal Research, v. 13, p. 12451255.
Crowell, M., Leatherman, S. P., and Buckley, M. K., 1991, Historical shoreline change; Error analysis and mapping accuracy: Journal of Coastal Research, v. 7, p. 839-852.

Daniels, R. C., and Huxford, R. H., 2001, An error assessment of vector data derived from scanned National Ocean Service topographic sheets: Journal of Coastal Research, v. 17, p. 611-619.

Davis, G. H., 1987, Land subsidence and sea level rise on the Atlantic coastal plain of the United States: Environmental Geology Water Science, v. 10, p. 67-80.

Dean, R. G., and O'Brian, M. P., 1987, Florida's east coast inlets: Shoreline effects and recommended action: Coastal and Oceanographic Engineering Department, University of Florida, Rept. 87/017, 100p.

Dean, R. G., Cheng, J., and Malakar, S. B., 1998, Characteristics of the shoreline change along the sandy beaches of the state of Florida: An atlas: Florida Sea Grant Report UFL/ COEL-98/015, variable pagination.

De Beaumont, L. E., 1845, Lecons de geologie practique: Septieme lecon, Bertrand Paris, p. 221-252.

Dolan, R., Anders, F., and Kimball, S., 1985, Coastal erosion and accretion, in National Atlas of the United Sates of America: U.S. Geological Survey, Reston, Va.

Douglas, B. C., and Crowell, M., 2000, Long-term shoreline position prediction and error propagation: Journal of Coastal Research, v. 16, p. 145-152.

Everts, C. H., Battley, J. P., Jr., and Gibson, P. N., 1983, Shoreline movements Report 1, Cape Henry, Virginia to Cape Hatteras, North Carolina, 1849-1980: U. S. Army Corps of Engineers, Coastal Engineering Research Center, Technical Report CERC-83-1, 111p.

Fisher, J. J., 1962, Geomorphic expression of former inlets along the Outer Banks of North Carolina: unpub. MS thesis, University of North Carolina, Chapel Hill, 120p.

Florida Department of Environmental Protection, 2004, Hurricane Francis and Hurricane Jeanne: Bureau of Beaches and Coastal Systems, Tallahassee, FL., 88p.

Gayes, P. T., Schwab, W. C, Driscoll, N. W., Morton, R. A., Baldwin, W. E., Denny, J. J., Wright, E. E., Harris, M. S., Katuna, M. P., and Putney, T. R., 2003, Sediment dispersal pathways and conceptual sediment budget for a sediment starved embayment: Long Bay, SC: Proceedings Coastal Sediments '03, 14p.

Gilbert, G. K., 1885, The topographic features of lake shores: U.S. Geological Survey 5th Annual Report, p. 69-123.

Gornitz, V., and Lebedeff, S., 1987, Global sea level changes during the last century, in Nummedal, D., Pilkey, O. H., and Howard, J. D., eds., Sea-level Fluctuation and Coastal Evolution: Society of Economic Paleontologists and Mineralogists, Special Publication 41, p. 3-16. 
Griffin, M. M., and Henry, V. J., 1984, Historical changes in the mean high water shoreline of Georgia: Georgia Geologic Survey Bulletin 98, 96p.

Hayes, M. 0., 1994, The Georgia Bight barrier system, in Davis, R. A., ed., Geology of Holocene Barrier Islands: SpringerVerlag, Berlin, p. 233-304.

Hayes, M.O., Sexton, W.J., Colquhoun, D.J., Eckard, T.L., 1994, Evolution of the Santee/Pee Dee Delta complex, South Carolina, USA, in Kay, R., ed., Deltas of the World: Am. Soc. Civil Eng., New York, p. 54-64.

Hicks, S. D., 1968, Long-period variations in secular sea level trends; Shore and Beach, v. 36, p. 32-36.

Holdahl, S. R., and Morrison, N. L., 1974, Regional investigations of vertical crustal movements in the U.S using precise relevelings and mareograph data: Tectonophysics, v. 23, p. 373-390.

Hoyt, J. H., 1967, Barrier island formation: Geological Society of America Bulletin, v. 78. p. 1125-1135.

Hoyt, J. H., and Henry, V. J., 1971, Origin of capes and shoals along the southeastern coast of the United States: Geological Society of America Bulletin, v. 82, 59-66.

Krabill, W., Wright, C., Swift, R., Frederick, E., Manizade, S., Yungel, J., Martin, C., Sonntag, J., Duffy, M., Hulslander, W., and Brock, J., 2000, Airborne laser mapping of Assateague National Seashore Beach. Photogrammetric Engineering \& Remote Sensing, v. 66, p. 65-71.

Langley, S. K., Alexander, C. R., Bush, D. M., and Jackson, C. W., 2003, Modernizing shoreline change analysis in Georgia using topographic survey sheets in a GIS environment: Journal of Coastal Research Special Issue 38, p. 168-177.

Lyles, S. D., Hickman L. E., Jr., Debaugh, H. A., Jr., 1988, Sealevel variations for the United States 1855-1986: U.S. Department of Commerce, NOAA-NOS, Rockville Md., $182 p$.

Lennon, G., Neal, W. J., Bush, D. M., Pilkey, O. H., Stutz, M., and Bullock, J., 1996, Living with the South Carolina shore: Duke University Press, Durham, N.C., and 241p.

McGee, W. D., 1890, Encroachments of the sea: The Forum, v. 9, p. $437-449$.

Meade, R. H., 1982, Sources, sinks, and storage of river sediment in the Atlantic drainage of the United States: Journal of Geology, v. 90, p. 235-252.

Moore, L. J., 2000, Shoreline mapping techniques: Journal of Coastal Research, v. 16, p. 111-124

Morton, R. A., 1991, Accurate shoreline mapping: past, present, and future: American Society of Civil Engineers, Coastal Sediments ‘91, v. 1, p. 997-1010.
Morton, R. A., 1996, Geoindicators of coastal wetlands and shorelines, in Berger, A. R., and lams, W. J., eds., Geoindicators: Assessing rapid environmental changes in earth systems: A.A. Balkema, Rotterdam, p. 207-230.

Morton, R. A., 2002, Factors controlling storm impacts on coastal barriers and beaches - A preliminary basis for real-time forecasting: Journal of Coastal Research, v. 18, p. 486-501.

Morton, R. A., and Speed, F. M., 1998, Evaluation of shorelines and legal boundaries controlled by water levels on sandy beaches: Journal of Coastal Research, v. 14, p. 1373-1384.

Morton, R. A., Miller, T. L., and Moore, L. J., 2004, National assessment of shoreline change: Part 1: Historical shoreline changes and associated coastal land loss along the U.S. Gulf of Mexico: U.S. Geological Survey Open-File Report 2004-1043 (http://pubs.usgs.gov/of/2004/1043/).

Moslow, T. F., and Heron, S. D., 1994, The Outer Banks of North Carolina, in Davis, R. A., ed., Geology of Holocene Barrier Islands: Springer-Verlag, Berlin, p. 47-74.

North Carolina Division of Coastal Management, 2004, Longterm average annual shoreline change study and setback factors updated through 1998: N.C. Department of Environment, and Natural Resources, Raleigh, http://dcm2. enr.state.nc.us/Maps/ER_1998/SB_Factor.htm.

Nummedal, D., Oertel, G. F., Hubbard, D. K., and Hine, A. C., 1977, Tidal inlet variability - Cape Hatteras to Cape Canaveral: American Society of Civil Engineers, Coastal Sediments '77, p. 543-562.

Pajak, M. J., and Leatherman, S. P., 2002, The high water line as shoreline indicator: Journal of Coastal Research, v. 18, p. 329-337.

Pilkey, 0. H., and Clayton, T. D., 1990, Summary of beach replenishment experience on U.S. East coast barrier islands: Journal of Coastal Research, v. 5, p. 147-159.

Pilkey, O. H., Jr., Sharma, D. C., Wanless, H. R., Doyle, L. J., Pilkey, O. H., Sr., Neal, W. J., and Gruver, B. L., 1984, Living with the East Florida shore: Duke University Press, Durham, N.C., 222p.

Pilkey, O. H., Jr., Neal, W. J., Riggs, S. R., Webb, C. A., Bush, D. M., Pilkey, D. F., Bullock, J, and Cowan, B. A., 1998, The North Carolina shore and its barrier islands: Duke University Press, Durham, N.C., 318p.

Redfield, A. C., 1958, The influence of the continental shelf on the tides of the Atlantic coast of the United States: Journal of Marine Research, v. 17, p. 432-448.

Riggs, S. R., Cleary, W. J., and Snyder, S. W., 1995, Influence of inherited geologic framework on barrier shoreface morphology and dynamics: Marine Geology, v. 126, p. 213234. 
Riggs, S. R., and Ames, D. V., 2003, Drowning the North Carolina coast: sea-level rise and estuarine shoreline erosion: Report prepared for the North Carolina Department of Environment and Natural Resources Division of Coastal Management, Raleigh.

Ruggiero, P., Kaminsky, G. M., and Gelfenbaum, G., 2003, Linking proxy-based and datum-based shorelines on a high-energy coastline: Implications for shoreline change analyses: Journal of Coastal Research Special Issue 38, p. 57-82.

Sallenger, A. H., Krabill, W., Swift, R., Brock, J., List, J., Hansen, M., Holman, R. A., Manizade, S., Sontag, J., Meredith, A., Morgan, K., Yunkel, J. K., Frederick, E. and Stockdon, H., 2003, Evaluation of airborne scanning lidar for coastal change applications: Journal of Coastal Research, v.19, p. 125-133.

Schwartz, M. L., 1971, The multiple causality of barrier islands: Journal of Geology, v. 79, p. 91-94.

Schwartz, R. K., and Musialowski, F. R., 1977, Nearshore disposal: Onshore sediment transport: American Society of Civil Engineers, Coastal Sediments '77, p. 85-101.

Shalowitz, A. L., 1964, Shore and sea boundaries. Publication 10-1, U.S. Department of Commerce, Washington, DC, 749p.

Simpson, R. H., and Lawrence, M. B., 1971, Atlantic hurricane frequencies along the U.S. coastline: National Oceanic and Atmospheric Administration, NOAA Technical Memorandum NWS SR-581, 15p.

Stauble, D. K., and Brumbaugh, R. W., 2003, An assessment of the nation's shorelines, USA: Shore and Beach, v. 71, p. 11-18.

Stockdon, H. F., Sallenger, A. H., List, J. H., and Holman, R. A., 2002, Estimation of shoreline position and change from airborne topographic lidar data: Journal of Coastal Research, v. 18, p. 502-513.

The Heinz Center, 2000, Evaluation of erosion hazards: The $\mathrm{H}$. John Heinz III Center for Science, Economics and the Environment, Washington, D.C., 203p.

Thieler, E. R., and Danforth, W. W., 1994, Historical shoreline mapping (1). Improving techniques and reducing positioning errors: Journal of Coastal Research, v. 10, p. 549-563.

Thieler, E.R., Himmelstoss, E.A., Zichichi, J.L., and Miller, T.L., 2005, Digital Shoreline Analysis System (DSAS) version 3.0; An ArcGIS extension for calculating shoreline change: U.S. Geological Survey Open-File Report 2005-1304.

U.S. Army Corps of Engineers, 1971, National shoreline study: Washington, D.C.

Valverde, H. R., Trembanis, A. C., and Pilkey, O. H., 1999, Summary of beach nourishment episodes on the U.S. East Coast barrier island: Journal of Coastal Research, v. 15, p. 1100-1118.
Weber, K. M., List, J. H., and Morgan, K. L. M., 2005, An operational mean high water datum for determination of shoreline position from topographic lidar data: U.S. Geological Survey Open-File report 2005-1027.

White, W. A., Morton, R. A., Kerr, R. S., Kuenzi, W. D., and Brogden, W. B., 1978, Land and water resources, historical changes, and dune criticality, Mustang and North Padre Islands, Texas: The University of Texas at Austin, Bureau of Economic Geology Report of Investigations No. 92, 46 p.

Wiegel, R.L., 1992. Dade County, Florida, beach nourishment and hurricane surge protection project: Shore and Beach, v. 60, p. 2-26. 